\title{
Psychiatric Opinions as to Credibility of Witnesses: A Suggested Approach
}

\author{
Michael Juviler*
}

T HE PSYCHOLOGICALIY abnomal witness can present a serious obstacle to fact finding in the judicial process. Almost any emotional or mental defect may materially affect the accuracy of testimony; a conservative list of such defects would have to include the psychoses, most or all of the neuroses; defects in the structure of the nervous system, mental deficiency, alcoholism, drug addiction and psychopathic personality. ${ }^{1}$ It is not surprising, therefore, that "the abnormal witness" has recently been the subject of considerable discussion. ${ }^{2}$

The need for psychiatric evaluation of testimony is one of the most important problems in forensic psychiatry and a fertile field for the application of behavioral science insights to the legal process. Unfortunately, investigation of the subject has proceeded haphazardly. There has been little attempt to relate psychiatric data to particular trial problems. Legal scholars are not formulating appropriate questions for the psychiatrist. Nor las there been an attempt to express psychiatric knowledge in language easily understood by the triers of fact and in language appropriate to the specific issues on trial. Perhaps the explanation for these shortcomings is that the lawyers have not clarified even for themselves the objectives to be achieved at the trial by the use of psychiatric knowledge.

In this article, after describing the present legal status of psychiatric opinions as to the credibility of witnesses, the writer will attempt to set forth a framework for the solution of these "law-science" problems. The framework then will be applied to four situations in which psychiatric

* A.B., Swarthmore College, 1956; IL.B., Yale Law School, 1960. This paper was originally presented in fulfillment of the requirements for the degree of Bachelor of Laws in the Division of Law and the Behavioral Sciences at Yale Law School.

1 For a summary of the behavior pathologies which may affect testimony, see Davidson, Testimonial Capacity, 39 B.U.L. REv. 172 (1959); Siegal, Inability to Remember-Its Analysis in Medicolegal Orientation, 45 J. Crom. L., C. \& P.S. 151 (1954); Note, Psychiatric Evaltaltion of the Mentally Abnormal Witness, 59 Yale L.J. 1324 (1950).

2 See note 1 supra; Guttacacher \& WeIrofen, Psychiatry and tire Law ch.11 (1952); Mack, Forensic Psycliatry and the Witness-A Survey, 7 Crev.-Mar. L. Rev. 302 (1958); Note, The Mentally Abnormal Witness: Challenges to His Competency and Credibility, 13 Rutgers L. Rev. 330 (1958); Note, Psychiatric Challenge of Witnesses, 9 VAND. L. Rev. 860 (1956) ; see also Conrad, Psychiatric Lie Detection-The Federal Courts Break with Tradition, 21 F.R.D. 199 (1958); cf. Louisell, The Psychologist in Today's Legal World, 39 Mrns. L. REv. 235 (1955), n.3 at p. 236, for a bibliography of the classic literature on scientific evaluation of testimony. 
opinions of credibility have been frequently offered: testimony by psychopathic personalities, prosecutions for rape, testimony by drug addicts, and personal injury actions brought by malingerers.

\section{I}

\section{COMPETENCY AND CREDIBIITY}

At the outset a few remarks about the relationship between competency and credibility are in order. The terms are often confused by the courts, ${ }^{8}$ but the distinction should be preserved for an understanding of the problems here to be considered. The term "competency" refers to qualification as a witness. ${ }^{4}$ At common law the mentally deranged and defective were incompetent, thoroughly disqualified as witnesses and excluded from testifying. ${ }^{5}$ This restriction was relaxed in 1851 by the English Court of Criminal Appeals, which ruled that a hallucinated mental patient could testify in his own defense in a prosecution for manslaughter, on the theory that the strict rule against deluded people "would have excluded Socrates." Thenceforth, freedom from derangement has not been a requirement of testifying. ${ }^{7}$ The test of competency under the modern rule is whether the person has sufficient capacity to observe, recollect and communicate the subject of the testimony. ${ }^{8}$ The requisite capacity to communicate includes the ability to understand and answer intelligently the questions of counsel, as well as a sense of moral responsibility to tell the truth; most courts also require that the witness "have sufficient understanding to apprehend the obligation of the oath."

The issue of competency is decided by the court, usually with the jury excused. ${ }^{10}$ Generally the hearing is limited to a voir dire examination of the

${ }^{3}$ See State v. Whitsett, 232 Mo. 511, 134 S.W. 555 (1911) (defendant could not prove insanity of prosecution witness whose competency was not challenged because evidence of insanity goes to "competency," a question for the court not the jury); Mell v. State. 133 Ark. 197, 202 S.W. 33 (1918) (no error to exclude testimony as to insanity in prosecutrix' family, no objection having been made to her "competency"); see also Commonwealth v. Repyneck, 181 Pa. Super. 630, 124 A.2d 693 (1956); Commonwealth v. Kosh, 305 Pa. 146, 157 Atl. 479 (1931).

4 See McCoranct, Evidence $\S 61$ (1954); 2 Wigmore, Evmence $\S 487$ (3d ed. 1940) [hereinafter citations to these works will be by author and section].

D 2 WigMORE § 492; see also MCCORMICT \$§ 61-62.

6 Regina v. Hill, 2 Denison 254, 169 Eng. Rep. 495, 499 (Crim. App. 1851).

7 District of Columbia v. Armes, 107 U.S. 519 (1883) (plaintiff in personal injury action whose mind was impaired by the accident may testify, the court following Regina v. Hill, suspra note 6). See also 2 Wigmore § 492 ; Annot., 148 A.L.R. 1140 (1944); Holcomb v. Holcomb, 28 Conn. 177 (1859) (lunatic may testify).

82 WIGMORE $\S 493-95$; see also 2 WIGMORE $\$ 478$.

9 District of Colunnbia v. Armes, 107 U.S. 519,521 (1883); Hutchins and Slesinger, Some Observations on the Law of Evidence: The Competency of Witnesses, 37 YaLE L.J. 1017 (1928).

10 District of Columbia v. Armes, supra note 9; State v. Moorison, 43 Wash. 2d 23, 259 P.2d 1105 (1953); McCorasIcr \$ 70; Hutchins and Slesinger, supra note 9. But cf. State v. Butler, 27 N.J. 560, 143 A.2d 530 (1958) (dictum that competency hearing may be in presence of jury, as the evidence also goes to credibility). 
prospective witness by the judge, but the trend is to admit extrinsic evidence as well, ${ }^{11}$ and courts have recently gone so far as to permit psychiatric opmions. ${ }^{12}$ At the hearing there is a presumption in favor of competency, ${ }^{13}$ and this is seldom overcome. The tendency is to qualify the witness if he can cast any light on the events in issue. ${ }^{14}$ Review on appeal is restricted to the issue of abuse of discretion, and a trial judge's decision that a challenged witness is competent is rarely reversed.15 Appellate courts have affirmed the competency of "lunatics,"16 inmates of mental hospitals, 17 narcotic addicts, ${ }^{18}$ epileptics, ${ }^{10}$ idiots and other mental defectives, ${ }^{20}$ and persons judged incapable of managing their affairs or business. ${ }^{21}$ Women who are too deranged to consent to intercourse have uniformly been held competent as complaining witnesses in rape cases where the trial judge has so ruled. ${ }^{22}$

The failure of the rules of competency to exclude pathological witnesses imposes heavy responsibility upon the weigher of credibility, usually a jury. After the judge rules that a mentally abnormal person is a competent witness, in other words, that he has the required capacities to observe, recollect and commumicate truthfully and intelligently, the jury must determine the extent to which the witness has these capacities, for they also affect credibility. The term "credibility" includes not only honesty, which the layman equates with credibility, but also other capacities for

11 See McCorance $\$ 70$; Note, 13 Rutgers L. Rev. 330 (1958). Compare Armstrong v. Timmons, 3 Harr. 342 (Del. 1840) (opinions of medical men as to witness's sanity admissible at competency hearing) with Aguilar v. State, 279 App. Div. 103, 108 N.Y.S.2d 456 (3d Dep't 1951) (error to exclude testimony of psychiatrist).

12 Taborsky v. State, 142 Conn. 619, 116 A.2d 433 (1955); State v. Butler, 27 N.J. 560, 143 A.2d 530 (1958); Commonwealth v. Repyneck, 181 Pa. Super. 630, 124 A.2d 693 (1956). See Mangrum v. State, 227 Ark. 381, 299 S.W.2d 80 (1957).

${ }_{18} 2$ WIGMORE $\$ \$ 484,497$.

142 WIGMORE \& 501; Hutchins and Slesinger, supra note 9.

18 A recent study discloses only two cases in which a trial court's decision in favor of competency was reversed. Note, 13 RutGers L. REv. 330, 335 n. 45 (1958).

16 Holcomb v. Holcomb, 28 Conn. 177 (1859).

17 Skelton v. State, 148 Neb. 30, 26 N.W.2d 378 (1947).

18 See Brown v. United States, 222 F.2d 293 (9th Cir. 1955); People v. Hamby, 6 Ill. 2d 559, 129 N.E.2d 746 (1955); Commonwealth v. Farrell, 319 Pa. 441, 181 Atl. 217 (1935); Conımonwealth v. Aikens, 179 Pa. Super. 501, 118 A.2d 205 (1955); State v. Concannon, 25 Wash. 327, 65 Pac. 534 (1901); State v. White, 10 Wash. 611, 39 Pac. 160 (1895).

19 People v. Enright, 256 IIl. 221, 99 N.E. 936 (1912).

20 People v. Hudson, 341 Ill. 187, 173 N.E. 278 (1930); Barker v. Washburn, 200 N.Y. 280, 93 N.E. 958 (1911).

21 Champion v. McCarthy, 228 Ml. 87, 81 N.E. 808 (1907); Barlser v. Wasbburn, supra note 20 .

22 State v. Simes, 12 Idaho 310, 85 Pac. 914 (1906); State v. Cosier, 39 Idaho 519, 228 Pac. 277 (1924); State v. Crouch, 130 Iowa 478, 107 N.W. 173 (1906); Hyde v. State, 26 OkJa. Crim. 69, 221 Pac. 787 (1924); State v. Leonard, 60 S.D. 144, 244 N.W. 88 (1932); see 2 WIGMORE \& 498. 
testifying. ${ }^{23}$ Thus, a nearsighted bishop may be less credible than a "psychopathic liar" with perfect vision; the psycopath lacks a sense of responsibility to tell the truth, but the clergyman has a defective capacity to observe.

\section{II}

\section{THE PSYCHIATRIC OPINION AS TO CREDIBIIITY}

For the party whose case depends upon testimony of a pathological witness, the liberal rules of competency are a blessing, but they are a curse for the legal system if juries are unable to evaluate credibility. The law needs a means by which psychiatry can make the jury aware of a witness's mental or emotional condition and, more important, of its effect upon his testimony. The principal method now employed falls far short of the mark. It is simply the traditional impeachment, by which testimony respecting a witness's mental incapacity is introduced as evidence affecting credibility. ${ }^{24}$ Under this primciple, courts have admitted proof of insanity or other mental disease, ${ }^{25}$ mental deficiency, ${ }^{26}$ and intoxication. ${ }^{27} \mathrm{~A}$ few courts have

232 Wiguore $\$ \$ 478,493-95$; see Weltacan, Tre ARt of Cross-Exanination 20-21 (1923); Ladd, Credibitity Tests-Current Trends, 89 U. PA. L. Rev. 166 (1940).

24 See 3 WIGLCORE $8 \S 931-35$; MCCORACCK $\$ 45$; cf, as to the other classical methods of impeachment, 3 WIGMORE $\$ \S 922-24,7$ WIGMORE $\$ 1985$, MCCORMxick $\$ \$ 41-42$, 44 (character); 3 Wigmore $\$ \S 980,987$, McCorartcr $\$ 43$ (previous conviction of a crime); 3 WigMore $\$ \$ 943-69$, McCosarick $\$ 40$ (bias, interest, motive, corruption); 3 WIGMore $\$ \$ 1005-15$, MCCoRMrres 847 (contradiction); 3 WIGMORE $\$ \$ 1017-46$, McCoranck $8 \$ 34-39$ (prior inconsistent statements).

25 Ingalls v. Ingalls, 257 Ala. 521, 59 So.2d 898 (1952) ("mental condition"); Thrash v. State, 146 Ark. 547, 226 S.W. 130 (1921) ("delusions") ; People v. La Rue, 62 Cal. App. 276, 216 Pac. 627 (1923) ("general paresis"-cross-exammation); Tutzle v. Russell, 2 Day 202 (Conn. 1805) ("insanity"); Holcomb v. Holcomb, 28 Conn. 177 (1859) ("insanity") ; Ellarson v. Ellarson, 198 App. Div. 103, 190 N.Y. Supp. 6 (3d Dep't 1921) ("mental condition"); Saucier v. State, 235 S.W.2d 903 (Tex. Crim. 1950) ("impairment of mind"); Fairchild v. Bascomb, 35 Vt. 398 (1862) ("brain disease"). Contra, Campbell v. State, 23 Ala. 44 (1853); People v. Mackey, 58 Cal. App. 123, 208 Pac. 135 (1922); People v. Enright, 256 Ill. 221, 99 N.E. 936 (1912); State v. Whitsett, 232 Mo. 511, 134 S.W. 555 (1911); see State v. Hayward, 62 Minn. 474, 65 N.W. 63 (1895); cf. Bowdle v. Detroit St. Ry., 103 Mich. 272, 61 N.W. 529 (1894).

${ }^{26}$ State v. Alberts, 199 Iowa 815, 202 N.W. 519 (1925); State v. Madena, 165 La. 474, 115 So. 661 (1928); Rivara v. Ghio, 3 E.D. Smith 264 (N.Y. Ct. of C.P. 1854); State v. Witherspoon, 210 N.C. 647 , 188 S.E. 111 (1936); Moyle v. Hopkins, 222 N.C. 33, 21 S.E.2d 826 (1942); State v. Armstrong, 232 N.C. 727, 62 S.E.2d 50 (1950); Bouldin v. State, 87 Tex. Crim. 419, 222 S.W. 555 (1920); see also Jeffers v. State, 145 Ga. 74, 88 S.E. 571 (1916); People v. Hudson, 341 Ill. 187, 173 N.E. 278 (1930). Contra, People v. Dye, 81 Cal. App. 2d 952, 185 P.2d 624 (1947); Blanchard v. People, 70 Colo. 555, 203 Pac. 662 (1922); State v. Spotted Hawk, 22 Mont. 33, 55 Pac. 1026 (1899); Bell v. Riner, 16 Ohio St. 46 (1864); Con1monwealth v. Myers, $5 \mathrm{~Pa}$. D. \& C. 410 (Cumberland County Ct. 1924); see Chicago West Division Ry. v. Bert, $69 \mathrm{Ill} .388$ (1873) (error to instruct jury that a witness may be impeached by his lack of intelligence); cf. Strand v. State, 36 Wyo. 78, 252 Pac. 1030 (1927) (admission of evidence that $I Q$ of ten-year-old rape prosecutrix was above normal "probably objectionable" but not reversible).

27 McCorance $\$ 45 ; 3$ WIGMroRe $\$ 933$. 
allowed extrinsic proof of weak memory. ${ }^{28}$ Evidence may consist of specific instances of delusions or other symptoms, ${ }^{29}$ and medical testimony as to the existence of a defect. ${ }^{30} \mathrm{~A}$ growing practice is to admit. adjudications of insanity, records of hospitalization and proof of psychiatric treatment. ${ }^{31}$

One flaw in this traditional method is that the raw evidence of the incapacity is presented to the trier of fact with no explanation of its effect on credibility. ${ }^{32}$ The modern technique, the psychiatric opinion, has the potential of correcting this flaw; under this method, not only is evidence of the defect presented to the trier of fact, but also a qualified expert gives his opinion as to the capacity of the witness to observe, recollect and communicate intelligently and truthfully. Whether the psycliatric opinion as to credibility raises more problems than it solves is one of the issues to be treated in the discussion which follows.

The most notable instance of the use of a psychiatric opinion of credibility was United States $v$. Hiss, ${ }^{33}$ involving a prosecution for perjury. The

28 Isler v. Dewey, 75 N.C. 466 (1876); Wren v. Howland, 33 Tex. Civ. App. 87, 75 S.W. 894 (1903). Contra, Ah Tong v. Earl Fuit Co., 112 Cal. 679, 45 Pac. 7 (1896); People v. Champion, 193 Cal. 441, 225 Pac. 278 (1924); Goodwyn v. Goodvryn, 20 Ga. 600 (1856).

29 E.g., Thrash v. State, 146 Ark. 547, 226 S.W. 130 (1921).

30 Ingalls v. Ingalls, 257 Ala. 521, 59 So.2d 898 (1952); Ellarson v. Ellarson, 198 App. Div. 103, 190 N.Y. Supp. 6 (3d Dep't 1921); State v. Armstrong, 232 N.C. 727, 62 S.E.2d 50 (1950); Lord v. Beard, 79 N.C. 5 (1878).

81 United States v. Pugliese, 153 F.2d 497 (2d Cir. 1945) (treatment in mental hospital); Bonner v. State, 59 Ga. App. 737, 1 S.E.2d 768 (1939) (adjudication of insanity) (dictum); State v. Browning, 98 Ohio App. 8, 128 N.E.2d 173 (1954) (past and present psychiatric treatment); Commonwealth v. Towber, $190 \mathrm{~Pa}$. Super. 93, 152 A.2d 917 (1959) (commitment for psychopathic disorder); Abbott v. Columbia Mills, 110 S.C. 298, 96 S.E. 556 (1918) (adjudication of insanity) State v. Moorison, 43 Wash. 2d 23, 259 P.2d 1105 (1953) (adjudication of insanity). Contra, Metropolitan Life Ins. Co. v. James, 228 Ala. 383, 153 So. 759 (1934) (evidence that witness had been inmate of asylum); State v. Spotted Havk, 22 Mont. 33, 55 Pac. 1026 (1899) (record of military discharge for insanity); Ellarson v. Ellarson, 198 App. Div. 103, 190 N.Y. Supp. 6 (3d Dep't 1921) (evidence that witnes; was once in a ward for the insane); cf. Jamison v. Corn Exchange Bank, 191 N.Y. Supp. 299 (3d Dep't 1921) (improper to admit record of commitinent containing statement that insanity might recur). Remoteness may lave been the unannounced basis of decision in many of these cases; not only must the form of evidence be not objectionable, but the incapacity nust be reasonably contemporaneous to the events witnessed or to the trial. Peckham v. United States, 210 F.2d 693 (D.C. Cir. 1953) (no error to exclude evidence of psychiatric treatment twenty months before trial); Garrett v. State, 105 So. 2d 541 (Ala. 1958) (no error to forbid cross-examination as to inental treatment prior to trial not contemporaneous with the matter about which testimony was given); Phillips v. Short, 2 Harr. 339 (Del. 1837) (proper to exclude attack of insanity wbich occurred between event testified to and trial).

82 See the opinion in Kelly v. Maryland Casualty Co., 45 F.2d 782 (W.D. Va. 1929), af'd, 45 F.2d 788 (4th Cir. 1930) ; People v. Williams, 6 N.Y.2d 18, 159 N.E.2d 549 (1959) (dissent).

3888 F. Supp. 559 (S.D.N.Y. 1950); see 185 F.2d 822 (2d Cir. 1950), cert. denied, 340 U.S. 948 (1951). The evidence bad been excluded at the first trial, the court permitting the psychiatrist to listen to a forty-five minute bypothetical question and then sustaining the government's objection. N.Y. Times, July 1, 1949, p. 1, col. 2, cited in Fallnor, Evidence, in 1950 ANN. SURVEY Ax. L. 804. 
defendant, Alger Hiss, attempted to impeach the crucial government witness, Whittaker Chambers, with psychiatric testimony that Chambers was a psychopathic personality disposed to making false accusations. The diagnosis was based upon a hypothetical question occupying twenty-three pages in the record (in most part a summary of facts testified to by Chambers), a study of Chambers' writings and translations, and observations of Chambers in court, and was supported by the testimony of a clinical psychologist who did not observe the witness in court. This evidence was admitted on the basis of the settled rule that a witness may be discredited by evidence of mental derangement and because the outcome of the trial depended to a great extent upon the testimony of one man.

It is difficult to assess the significance of the Hiss case from short perspective. Perhaps its principal effect has been to increase interest in psychiatric opinions of credibility on the part of legal scholars and practicing lawyers who are looking for devices to use for impeachment. Most of the scholarly comment, however, has been unfavorable. ${ }^{34}$. Doctrinally, the decision is a high point of judicial approval, rather than a pioneering "break with tradition," ${ }^{35}$ as there was already considerable authority favoring psychiatric evaluation of credibility. ${ }^{36}$ Courts had approved the adduction of psychiatric opinions as to the credibility of mental defectives, ${ }^{37}$ narcotic addicts, ${ }^{38}$ and hysterical complaining witnesses in rape cases. ${ }^{39}$ Courts had

34 OvERholser, The PSYchitatrist AND tHe LAw 55, 113 (1953); Falknor, supra note 33; Frank, Judicial Fact-Finding and Psychology, 14 Oнmо Sr. L.J. 183 (1953); Roche, TruthTelling, Psychiatric Expert Testimony and the Impeachment of Witnesses, 22 PA. B.A.Q. 140 (1951); Note, Courtroom Diagnosis-Valid or Invalid?, 30 NEB. L. Rev. 513 (1951). But see Conrad, supra note 2; Jones, Admission of Psychiatric Testimony in the Alger Hiss Trial, 11 Ala. Law. 212 (1950).

35 Cf. Conrad, Psychiatric Lie Detection-The Federal Couts Break with Tradition, supra note 2.

36 The earhest reported case holding admissible a psychiatric opinion as to credibility appears to be Alleman v. Stepp, 52 Iowa 626, 3 N.W. 636 (1879), affirming admission at the trial of a suit for recovery of a surgeon's fee the opimion of a physician as to the effect of illness and the operation on the defendant's memory, particularly with respect to money and finances; cf. Lord v. Beard, 79 N.C. 5 (1878) (physician may testify as to the effect of paralysis on the mind of an aged witness; it is not clear whether the testimony imcluded an opinion as to credibility, or merely an opinion as to the existence of a mental condition attributable to paralysis, with no elaboration about its effect on the capacity to observe, recollect or communicate).

37 People v. Joyce, 233 N.X. 61, 134 N.E. 836 (1922) (error to exclude expert testimony, offered to impeach a confession, that the defendant in a nuurder prosecution had the mind of a child and was easily influenced). Compare Abbott v. State, 113 Neb. 517, 204 N.W. 74 (1925) (sodomy with six-year-old girl; no error to exclude psychologist's testimony as to prosecutrix' susceptibility to parental suggestion).

38 E.g., Effinger v. Effinger, 48 Nev. 205, 239 Pac. 801 (1925); see Vamuas v. United States, 13 F.2d 347 (5th Cir. 1926). But cf. Kelly v. Maryland Casualty Co., 45 F.2d 782 (W.D. Va. 1929), aff'd, 45 F.2d 788 (4th Cir. 1930); Wilhams v. United States, 6 Indian Terr. 1, 88 S.W. 334 (1905) ; State v. King, 88 Mim. 175, 92 N.W. 965 (1903) ; Katleman v. State, 104 Neb. 62, 175 N.W. 671 (1919).

39 People v. Cowles, 246 Mich. 429, 224 N.W. 387 (1927); Miller v. State, 49 Okla. Crim. 133, 295 Pac. 403 (1930); State v. Perry, 41 W.Va. 641, 24 S.E. 634 (1896); see Derwin v. 
received not only opinions of physicians and psychiatrists, but also lay testimony of a "psychiatric" nature. ${ }^{40}$ In most of the reported cases the offer was made at the trial, but courts had also admitted psychiatric opinions of credibility on motions for a new trial on the ground of newly discovered evidence of witnesses' derangement. ${ }^{41}$

Since the Hiss case, the courts have remained divided. Offers continue in cases where, as in Hiss, conpetency is not in issue. ${ }^{42}$ They also have been made after competency was challenged and the witness qualified, thus presenting the novel question whether psychiatric opinions received at a hearing to determine competency are admissible at the trial on the issue of credibility. In Taborsky $v$. State $e^{43}$ a convicted nurderer petitioned for a new trial on the basis of newly discovered evidence of insanity of the main prosecution witness. The petition was dismissed although five of six psychiatrists testified at the hearing that the witness was incompetent at the time of trial, and all six agreed that he was schizophrenic. The Connecticut Supreme Court of Errors reversed, ruling that at the new trial psychiatric evidence could be used in passing on the witness's credibility. ${ }^{44}$ As the first

Parsons, 52 Mich. 425, 18 N.W. 200 (1884); State v. Wesler, 137 N.J.L. 311, 59 A.2d 834, $a f f d, 1$ N.J. 58, 61 A.2d 746 (1948); Rice v. State, 195 Wis. 181, 217 N.W. 697 (1928). But cf. State v. Driver, 88 W. Va. 479, 107 S.E. 189 (1921).

40 Jones v. State, 165 Miss. 810, 146 So. 138 (1933) (murder; error to exclude lay testimony that prosecution witness was incapable of understanding the oath and that his mental ability made him an unreliable witness); McClure v. Fall, 42 S.W.2d 821 (Tex. Civ. App. 1931) (deponent's credibility may be impeached by lay testimony that he did not have the mental capacity to dictate the answers in the deposition); see Kellner v. Randle, 165 S.W. 509 (Tex. Civ. App. 1914) ; cf. Craig v. United States, 81 F.2d 816 (9th Cir. 1936). Although such testimony is not based on specialized training, it avoids the sensational sidt-effects of bringing a psychiatrist to the stand and often is easier to understand and puore relevant to the issues on trial than expert testimony by a psychiatrist.

41 Hines v. State, 37 Tez. Crim. 339, 39 S.W. 935 (1897) ; cf. Note, 13 Rutcers I. Rev. 330 (1958) for a discussion of newly discovered evidence of noncredibility as a basis for a new trial.

42 As each case is almost in a category by itself with respect to the incapacity referred to in the opinion and the diagnostic method used by the expert witness, indiscriminate counting of decisions for and agamst admissibility would be of little value in determining the judicial attitude toward psychiatric evidence. The cases will be discussed below in separate sections of the article devoted to the subjects of the psychiatric opinions. See also United States v. Rosenberg, 108 F. Supp. 798, 806 (S.D.N.Y. 1952), affd, 200 F.2d 666 (2d Cir. 1952), cert. denied, 345 U.S. 965 (1953), rehearing denied, 345 U.S. 1003 (1953).

43142 Conn. 619, 116 A.2d 433 (1955); see State v. Butler, 27 N.J. 560, 143 A.2d 530 (1958) (dictum that psychiatric testimony received at a competency hearing could be presented to the jury as affecting credibility); see also notes 12 and 41 supra and supported text.

44116 A.2d at 438 . The defendant was acquitted at the second trial. Chicago Tribune, Oct. 15, 1955, p. 19, col. 1, cited in Note, 9 VAND. L. Rev. 860 (1956). But cf. People v. Salemi, 309 N.Y. 208, 128 N.E.2d 377 (1955) (prosecution witness committed to mental institution as psychotic the day after the jury returned verdict of guilty; new trial denied); Coleman v. Commonwealth, $66 \mathrm{Va}$. (25 Gratt.) 865 (1874) (newly discovered evidence that prosecution witness was deranged before and after testifying; new trial denied). 
pronouncement of an appellate court of Connecticut in almost a century on the use of psychiatric evidence to impeach ${ }^{45}$ a witness, the Taborsky case should be influential in inducing a favorable attitude toward the use of such evidence. Courts of two other states, however, have reached contrary results on similar facts. ${ }^{46}$

Despite the ambivalent attitude of the judiciary toward the psychiatric evaluation of credibility, the legal system will continue to be concerned with the problem because of the importance of evaluating testimony and the progress in psychiatry. ${ }^{47}$ Indicative of this interest are ambitious proposals for scientific examination of witnesses. A report prepared for the World Health Organization, for example, recommends the establishment of scientific institutes for the examination of witnesses and offenders, with a psychiatric division, a division to prepare "sociomedical case histories," and a medical division to examine witnesses alleged to be ill and complainants in rape cases. ${ }^{48}$ Two commentators favor the use of standardized intelligence tests to determine competency. If the subject were qualified, the results could conveniently be offered on the question of credibility.$^{49}$ Judge Jerome N. Frank proposed the use of "testimonial experts," a psychiatrist and a psychologist, to examine witnesses and report to the trial court as to defects in perception, memory and communication. ${ }^{50}$ Another student

45 See Holcomb v. Holcomb, 28 Conn. 177 (1859) (lunatic may testify, but lay testimony as to his insanity admissible to affect credibility).

46 Mangrum v. State, 227 Ark. 381, 299 S.W.2d 80 (1957) (no error to exclude from the jury expert testimony adduced at competency hearing that prosecuting witness was mentally retarded and easily influenced); Commonwealth v. Repyneck, 181 Pa. Super. 630, 124 A.2d 693 (1956) (at hearing on the competence of alleged eyewitness, psychiatric testimony that he was a pathological liar was adduced; exclusion from jury upheld). Taborsky may be distinguished on the ground that in Taborsky there was no specific request at the trial to have the testimony adunitted.

47 "The warning has been sounded against embarking-- without a pilot, rudder, compass or radar-on an amateur's voyage on the fog-enshrouded sea of psychiatry' (Frank, J., concurrimg, United States v. Flores-Rodrigues, 2 Cir., 237 F.2d 405, 412) [sic]. But the courts, in the cited cases as well as in others, are compelled-with or without benefit of jury-to deal with and to evaluate medical proof." Herlands, D.J., in Markakis v. Liberian S/S The Mparmpa Christos, 161 F. Supp. 487, 499 (S.D.N.Y.1958), a personal injury action producing over 2500 pages of psychiatric and medical testimony, and an opinion with perceptive remarks on the problems raised for the courts by psychiatric evidence.

48 Guttmacher, Psychiatric Examination of Offenders, 2 BuLr. WorLd HEALTH ORG. 743 (1950), cited in GutTAracher \& WeIHOFen, op. cit. supra note 2, at 266-68. The psychiatric division as proposed would examine offenders only, but the plan easily lends itself to coverage of ordinary witnesses.

49 Hutchins and Slesinger, supra note 9 ; cf. notes 43,44 and 46 supra, on the subject of admissibihity at trial of psychiatric evidence received at a competency hearing; see note 26 supra, as to admissibility of evidence of mental deficiency.

${ }^{50}$ Frank, supra note 34; see also Wigmore, Jusry-trial Rules of Evidence in the Next Cen- tury, in 1 Law; A Century of Progress, 1835-1935, at 347 (1937), cited in Roche, supra note 34 at $147 ; c f .3$ WIGMORE $\$ 875$. 
of forensic psychiatry endorses courtroom diagnosis, with a psychiatrist supervising the direct and cross-examination of abnormal witnesses. ${ }^{\text {DI }}$

These proposals are not isolated ripples, but part of a powerful current of modern legal thought, the "behavioral science" or "law-science" approach, which seeks "an application of the methods and findings of the bchavioral sciences to the law." forensic areas where psychiatry is applied, such as determination of testamentary and contractual capacity, hospitalization of the mentally ill, and assessment of criminal responsibility. ${ }^{53}$ It is sorely lacking, however, in the field of psychiatric evaluation of credibility. The remainder of this article will be devoted to suggestions for future study in this area.

III

\section{A FRAMEWORK FOR FUTURE STUDY OF THE PSYCAIATRIC OPINION}

\section{AS TO CREDIBILITY}

The attainment of the ideal lies, perhaps, in the answers to the following questions: From the viewpoint of society, what policies are to be effected at a trial? What information is needed from the psychiatrists to further these policies? When the information is obtained, how can it effectively be applied at the trial?

\section{A. From the Viewpoint of Society, What Policies are to be Effected at a Trial?}

Students of psychiatric evaluation of credibility must determine what they wish to accomphish at a trial before they can determine what psychiatric information is needed or how it can be applied. The first task, therefore, is to identify objectives. The following list of some of the policies to be effected at a trial is presented to illustrate these objectives and to clarify the ensuing discussion:

1. Achieve a just verdict as between the parties by:

(a) allowing only competent and qualified witnesses;

(b) enabling the triers of fact to judge the credibility of the witnesses;

(c) receiving only relevant evidence;

(d) avoiding auxiliary side effects of the evidence;

(e) allowing only the legally designated triers of fact to decide questions of fact; and

61 Note, 59 YaIE L.J. 1324 (1950). However, the primary recommenclation of the authority cited is clinical examination.

62 1959-1960 Bulletin of the Yale Law School, p. 43. "The fundamental tenet of the law-science approach can be simply stated: In an age of science, those human principles designed to regulate human conduct ('rules of law') should be firmly grounded upon insights developed by the various sciences." Cady, Legal Relations of the Mentally Ill: A Functional Approach, 14 Omio Sr. L.J. 154, 155 (1953). 
(f) resting the verdict on correct principles of law.

2. Minimize the harm done in achieving a just verdict by:

(a) minimizing expense and delay; and

(b) minimizing the harm done witnesses and others.

\section{B. What Information is Needed From the Psychiatrists to Further These Policies?}

Lawyers must formulate appropriate questions for the psychiatrists with respect to each of these policies. For example, to effect the policy of enabling the triers of fact to judge credibility, two key questions might direct future psychiatric research along proper lines: (1) what mental conditions are hikely to affect a person's capacity to observe, to recollect what he has observed, and to communicate what he has observed truthfully and intelligently; (2) what precisely is the effect of these conditions on observation, recollection and communication? Of course the ultimate inquiry must be with reference to particular behavior traits and their effect upon particular subjects of testimony, these special problems will be taken up later when the framework is applied to specific situations. ${ }^{\text {s4 }}$

Another policy to be effected at the trial is that only relevant evidence be received. Thus, when psychiatric opinions as to credibility are offered in evidence, courts must determme their relevancy, or "probative value." This is one of the most vexing problems raised by this type of evidence. What, for example, is the probative value of a psychiatric opinion based upon an observation of the witness in court, or of an opmion that the witness has a "character disorder" which makes him a liar? The answers to such questions depend upon the standard of probative value adopted by the legal system and the proper application of that standard to each offer of proof. While psychiatrists cannot help lawyers to identify the standard, ${ }^{68}$ they can provide information which would facilitate its application.

54 See also Mack, Forensic Psychiatry and the Witness-A Survey, 7 CLEve.-MAR. L. REv. 302 (1958). In the reported survey, fifty psychiatrists were asked whether twelve clinical conditions "might affect the capacity of a witness to testify." The responses of the psychiatrists were tabulated in columns marked "Yes," "No" and "In Some Cases." Psychoneurosis "scored" lowest (Yes: 15, No: 15, In Some Cases: 17) ; manic states "scored" highest (Yes: 29, No: 1, In Some Cases: 19). The importance of this study is minimal because of the equivocal method of tabulating the answers, failure to define the "capacity" to testify, failure to determine precisely the effect which each imcapacity "might" have, absence of relation to specific subjects of testimony, and broadness of classification of some of the mcapacities. However, the work is a step in the direction pointed out in this article, although encountering pitfalls along the way.

65 See McCormick $\$ \S 151-52$.

58 One of the greatest obstacles to commumication between law and psychiatry is the failure to realize the difference between the standards and values of the two disciplines, with consequent misapplication of the standards of one to situations in the other. See West, The Importance of Modern Psychiatry to the Lawyer, 14 OHzo Sr. L.J. 138 (1953).

Consider, for example, the different attitudes toward diagnosis. "The doctor is primarily concerned with effecting a change. ... The facts necessary to fully efficient action may or may not be known. The doctor picks out salient facts and hurries on to do the best he can. The 
The prevalent test of the probative value of scientific evidence is whether the techniques or theories upon which they are based have won "general acceptance" among scientists in the field. ${ }^{57}$ This is the only test of approval which has been stated in decisions involving psychiatric opinions of credibility, although more relaxed standards than general agreement have been applied to other scientific sources of proof. ${ }^{68}$ Failure to nieet this test has resulted in inadmissibility of expert opinions as to the credibility of narcotic addicts, ${ }^{69}$ psychopaths, ${ }^{60}$ and pathological complaining witnesses in sex cases. ${ }^{61}$ The requirement of general scientific acceptance has been approved also by students of the psychiatric evaluation of testimony..$^{62}$

In applying this legal test to specific offers of proof, the courts should turn to psychiatrists for information. For example, a juclge would have to know the professional view of various methods and techniques of psychiatric evaluation in order to estimate whether a specific offer of proof based upon a particular technique fulfilled the standard of general scientific acceptance. Courts must also determine the degree of acceptance of the classifications of the incapacities implicit in psychiatric opinions. To what extent are psychiatrists in agreement, for example, that the concept

lawyer, on the other hand, is trained to seize facts, cast them into established formulac, build cases of merit upon them, and judge such cases with considerable attention to verbal niceties. The presumptions of authority and the judicial process concentrate attention upon formulations and nuances, re-examination and reconsideration. . . . A lawyer asked to consider a medical problem would tend to concentrate on diagnosis and linger there, while the physician who directs his attention to politics will nearly always he a missionary anxious to get something done." Ibid. Cf. Murphy, Bolinger and Ferriman, Screening Neuropsychiatric Patients by Meares of the Kahn Test of Symbol Arrangement, 3 BEHAv. Scr. 344 (1958): "[T] he practitioner in the mental health field can afford to concentrate on the treatment of his patients, often letting the matter of diagnosis go until therapeutic relationships have been well esablished."

57 Frye v. Umited States, 293 Fed. 1013, 1014 (D.C. Cir. 1923): "[T]he thing from which the deduction is made must be sufficiently established to have gained general acceptance in the particular field in which it helongs." Applying this standard, the court held inadmissible the results of a lie detector test.

68 See McCorance $\$ 170$.

89 Kelly v. Maryland Casualty Co., 45 F.2d 782 (W.D. Va. 1929), aff'd, 45 F.2d 788 (4th Cir. 1930); People v. Bell, 138 Cal. App. 2d 7, 291 P.2d 150 (1956) ; People v. Williams, 6 N.Y.2d 18, 159 N.E.2d 549 (1959).

60 Commonwealth v. Repyneck, 181 Pa. Super. 630, 124 A.2d 693 (1956).

61 State v. Driver, 88 W. Va. 479, 107 S.E. 189 (1921). See Lindsey v..United States, 237 F.2d 893 (9th Cir. 1956) (prosecution attempted to rehahilitate complaining witness's credibility by testimony of a psychiatrist as to the results of a narcoanalytic examination; court reserved decision whether results of a narcoanalytic interview are competent as the basis of an opinion of the subject's credibility, excluding the evidence on other grounds, but expressed disapproval of the evidence for failure to meet the test of scientific acceptance).

623 WIGMrore \$ 875; Roche, supra note 34 at 153; Falknor and Steffen, Evidence of Character: From the "Crucible of the Communily" to the "Couch of the Psychiatrist," 102 U. PA. L. Rev. 980, 988, (1954). But see McCormick, Deception-Tests and the Law of Evidence, 15 CAITF. L. Rev. 484, 500 (1927); MCCoRMICK \& 170, at 363. 
"psychopathic personality" is a valid basis for an opinion of credibility? Failure to inquire as to the degree of professional acceptance may result in unjustified approval ${ }^{63}$ or disapproval of the evidence.

The probative value of psychiatric opinions of credibility will also depend upon the degree to which theories as to the effect of the incapacities on observation, recollection and communication have won general acceptance. Without this guiding material, conscientious courts liave liad to pursue their own arduous research, ${ }^{64}$ a job for which they are not institutionally equipped.

Once courts are able to learn from psychiatrists low much acceptance there is of (1) the method or technique of psychiatric evaluation upon which an opinion as to credibility is based, ${ }^{65}$ of (2) the mode of classification imphicit in the opinion, and of (3) the theory relating to the effect of the mental condition upon credibility, ${ }^{B 6}$ and once they are equipped with a legal standard of scientific acceptance, they will be safer from shipwreck in the psychiatric mist. There are, however, other policies to be effected at a trial whicl must be considered by students interested in formulating a guide to future psychiatric research.

Psychiatric opinions of credibility may be "relevant" but have a confusing or prejudicial effect on the jury, thereby conflicting with the policy

63 Consider, for instance, Note, 59 YaIs L.J. 1324, 1337 (1950), wherein the editor recommends videspread psychiatric evaluation of credibility, states that "the notion that psychiatry lacks definite guideposts for classifying the minor disorders and defects overlooks the realities of modern medicine," and offers in support the action of the United States Government in discharging 500,000 soldiers in World War II for various sub-psychotic disorders, including neurosis and psychopathic personality. This confidence in military psychiatric classification is refuted by a study of the 100,000 men examined at induction stations in the United States in August 1945, which reveals large variations in the standards of classifications used by Army examiners. A psychiatric screening test given the men provided a uniform scoring device against which variability in the diagnoses and dispositions made by the examining physicians could be compared. The test scores had about the same frequency distribution throughout the country, but proportions of those rejected on psychiatric grounds by the examiners varied from $.5 \%$ of the men at one station to $50.6 \%$ at another. Reasons for rejections also fluctuated. The proportion of rejects who were "psychoneurotic" varied from $2.7 \%$ in one location to $90.2 \%$ in another; the "psychopathic" varied from $0 \%$ to $81.3 \%$ of rejects. Stouffer, Indices of Psychological Illness, in Language of Soctal Researci 63 (Lazarsfeld \& Rosenberg ed. 1955).

B4 See Kelly v. Maryland Casualty Co., 45 F.2d 782, 784 (W.D. Va. 1929), aff'd, 45 F.2d 788 (4th Cir. 1930) (McDowell, D.J., read "all the medical works" he could "reasonably obtain" before excluding a medical opinion as to the effect of morphine addiction on credibility) ; see also People v. Williams, 6 N.Y.2d 18, 159 N.E.2d 549 (1959); Lindsey v. United States, 237 F.2d 893 (9th Cir. 1956) ; People v. Ford, 304 N.Y. 679, 107 N.E.2d 595 (1952) (dissent).

65 Cf. Mack, supra note 54. The psychiatrists surveyed were asked whether courtroom observation of a witness would be effective to determine his capacity to testify. They responded as follows: Yes: 5; No: 16; In Some Cases: 26; When Indicated By Overt Behavior: 19. See note 54 supra.

${ }^{66}$ The survey discussed in notes 54 and 65 supra, indicates to some extent the answers to this question, but the results are not a basis for guiding the conduct of courts or lawyers. 
against side effects that preclude a just verdict. ${ }^{67}$ Or they may be "too" probative and overestimated by the jury to the extent that the psychiatrist's opinion is substituted for that of the jury, thereby conflicting with the policy that only designated individuals should decide the issues. ${ }^{98}$ They may also protract the trial, an occurrence which, aside from confusing the jury, undermines the policy of avoiding expense and delay. ${ }^{69}$ To avoid these consequences, courts have evolved the rule that an expert's opinion is admissible only if his skill with respect to the subject of testimony is greater than that of the jury. ${ }^{70}$ The issue in applying this rule is not whether the witness is qualified to give an opinion, but whether the average person is not also qualified. This is another area where information from psychiatry would aid the judiciary. Without citing any scientific support, courts have stated in their opinions that one man as well as another might form an opinion of a witness's power to recollect, ${ }^{71}$ but that only experts can determine whether a witness is unable to remember ${ }^{72}$ that layinen can draw conclusions as to the effect of morphine on credibility, ${ }^{78}$ but that the effect of chloroform is a inatter for experts. ${ }^{74}$ Questions which psychiatry may answer for the judicial systein, thus resolving these issues, might include the following: (1) which of the emotional or inental conditions likely to affect credibility cannot be detected without aid of psychiatric training;

67 See People v. Williams, 6 N.Y.2d 18, 27, 159 N.E.2d 549, 554 (1959) for a classical statement of the problem; see also State v. King, 88 Minn. 175, 92 N.W. 965 (1903); Fries v. Berberich, 177 S.W.2d 640 (Mo. Ct. App. 1944); Abbott v. State, 113 Neb. 517,204 N.W. 74 (1925). Cf. Blanchard v. People, 70 Colo. 555, 203 Pac. 662 (1922); Goodwyn v. Goodwyn, $20 \mathrm{Ga} .600$ (1856); Bell v. Rinner, 16 Ohio St. 46 (1864).

68 See People v. Williams, supra note 67, at 554 ("such expert testimony would unquestionably have great impact upon a jury and, to some unknowable extent, replace their judgment by the opinion of the expert. ..."); Criglow v. State, 183 Ark. 407, 410, 36 S.W.2d 400, 401 (1931) ("[T]he function of passing upon the credibility and weight of testimony could not be taken from the jury."); State v. Driver, 88 W.Va. 479, 487, 107 S.E. 189, 192 (1921) ("an attempt ... to substitute the opinion of the experts for that of the jury"); see also Abbott v. State, supra note 67; Williams v. United States, 6 Indian Terr. 1, 88 S.W. 334 (1904). Cf. United States v. Rosenberg, 108 F. Supp. 798, 806 (S.D.N.Y. 1952).

If the expert witness is really an expert, and if only an expert can draw the necessary inferences, he may be giving the jury valuable information, and stock judicial phrases such as "usurping the province of the jury " hardly seem appropriate.

${ }^{69}$ See Mangrum v. State, 227 Ark. 381, 299 S.W.2d 80, 84-85 (1957) (". . the trial judge should have discretion to decide whether the trial should be prolonged by calling witnesses to give their opinions to the jury.") McCorance \& 170, at 363-64; 1 WIoMrore $89 ; 3$ WIOMrore \$877.

70 MCCOR3ATCK \& 13; 7 WIGMORE \& 1917.

71 Criglow v. State, 183 Ark. 407, 410, 36 S.W.2d 400, 401 (1931).

72 Fries v. Berberich, 177 S.W.2d 640 (Mo. 1944). And compare Canipanale v. Metropohtan Life Ins. Co., 290 Mass. 149, 194 N.E. 831 (1935) with Cole v. Lake Shore \& M.S. Ry., 95 Mich. 77, 54 N.W. 638 (1893).

73 Katleman v. State, 104 Neb. 62, 175 N.W. 671 (1919).

74 State v. Perry, 41 W.Va. 641, 24 S.E. 634 (1896). 
(2) which conditions, once recognized, require specialized training before the precise effect on credibility can be determined?

\section{When the Information is Obtained, How Can it Effectively be Applied at the Trial?}

Even if it is assumed that the participants in the judicial system are aware of the mental and emotional conditions and their effect upon credibility, that the theories and techniques upon which psychiatric conclusions are based are sufficiently "probative," and that there is a need for expert testimony which outweighs its possible detrimental effects, other problems still must be solved before psychiatric testimony as to credibility would be suitable as an accepted forensic tool. These are the practical problems of presenting the evidence at the trial.

\section{Communication Between Psychiatrist and Jury}

The utility of much psychiatric information presented during a trial is destroyed because it is not adapted to the specific purposes for which it was adduced. The information is occult, its weight undisclosed, or its relationship to the issues unexplained..$^{75}$ Lawyers and the courts do not make clear to the psychiatrists precisely what they want to know. Even when lawyers have articulated for themselves what they want to learn from the psychiatrists, they still may not communicate their ideas, since lawyers and psychiatrists do not always speak the same language. They often use technical words without explaining the meanings to each other ${ }^{76}$ for example, when a lawyer inquires as to the "capacity" of a witness to testify, he may neglect to designate the components of that "capacity."

The crudeness of psychiatric opinions expressed in court is also attributable to the failure of lawyers and judges to see that the information is presented to the jury in the correct terms. Consider, for example, the following diagnosis appearing in one of the leading cases of judicial approval of psychiatric evaluation of a witness's capacity to testify:

Chronic brain syndrome associated with convulsive disorder with behavior reaction....

[W] as functioning within a noderate defective range of intelligence ... he is an anxious and insecure individual who tries to avoid all difficult life situations ... when confronted with unavoidable difficulties he may try to bluff through them or become panic stricken and respond with a gross emotional outburst resembling a temper tantrum. ${ }^{78}$

75 See Cady, suspra note 52, at 155; West, supra note 56, at 138.

76 See Cady, suspra note 52, at 154-55.

77 E.g., Mack, sispra note 54. For an example of a failure of communication between the two disciplines over the concept "incapacity," cf. Curran, Expert Psychiatric Evidence of Personality Traits, 103 U. PA. L. REv. 999, 1009 (1955). An instance of a conscious attempt to solve the problems discussed in the text is presented in the Appendix, infra.

78 State v. Butler, 27 N.J. 560, 598, 143 A.2d 530, 552 (1958). The quotation is from the court's account of the testimony. 
This illustrates three typical faults of the language in which psychiatric opinions are expressed in court. The first is the use of such terns as "chronic brain syndrome," "convulsive disorder," "behavior reaction," and "moderate defective," which may be incomprchensible to juries of laymen and to judges who have not had specialized training. Psychiatric testimony will be of little aid to the jurors unless they understand the language of the testinony. Judging from the situations which have arisen, lawyers do not understand this platitude. ${ }^{79} \mathrm{~A}$ second flaw is the use of common terms having technical meanings, such as "panic" in the exerpt above, without an indication of the sense in which the terms are being used. ${ }^{80}$ The third common fault is the failure of the language to focus upon the issue in controversy, in this case the capacity of a witness to observe, recollect and communicate. Subject to the requirement that the expert state the basis of his opinion, ${ }^{81}$ words which do not have a direct bearing upon the issues at the proceeding should not be used, since they may have prejudicial or confusing sideeffects. ${ }^{82}$

Not all psychiatric testimony is subject to these criticisms. Consider, for example, the following testimony bearing on the capacity of a blind, inentally defective nine-year old boy to testify as the prosecuting witness in a trial for sodomy:

He is easily dominated, highly over-protected by those close to him. If this person is close enough to him, he could be made to believe (anything told him by such person) ... He doesn't think fast, because of this emotional immaturity. He doesn't think fast because of a low intelligence quotient sometimes mistaken for hard of hearing ... I feel that Eddie cannot give a comprehensive detailed description of any eight hour period regardless of lapse of time involved without a certain amount of instruction. . . . ${ }^{83}$

79 For other examples of obscure raw psychiatric data received on the issue of testimonial capacity, see Note, 13 Rutgers L. REv. 330 (1958). One could argue that an opinion is not "relevant," namely, that it has no tendency to prove anything in issue, if it cannot be understood. There appear to be no reported cases in which the objection of irrelevancy was raised to psychiatric opinions because specific language was unclear.

80 Webster, New Coltegtate Dictionary (1953): "Panic . . . A sudden, overpowering frigbt esp. when groundless"; Casreron \& Magaret, Behaviour Patrology 306 (1951); "The paric reaction is a maximal episode of unconsummated emotional excitement." (Emphasis omitted.) Cf. Falknor and Steffan, supra note 62, at 991, for another illustration of this problem in the use of the word "deviate" in psychiatric testimony.

81 MCCormuck \& 14.

82 See Roche, supre note 34 , criticizing the use of the term "psychopathic personality" because it entails extremely prejudicial side-effects; cf. Brown v. Third Ave. Ry., 19 Misc. 504, 43 N.Y.S. 1094 (1st Dep't 1897) (action for loss of services; proper to exclude question to defendant's medical witness whether plaintiff's wife was a "malingerer," as the term is one characterizing the witness, injplying deception or perjury); Yelverton v. Louisiana Cent. Lumber Co., 19 La. App. 21, 138 So. 684, 686 (1932) (stating that "gross mjustice might be done to an innocent party" by characterizing him as a "inalingerer").

83 Mangrum v. State, 227 Ark. 381, 384, 299 S.W.2d 80, 82 (1957); see also note 40 supra. 


\section{Judicial Power to Order Psychiatric Examinations of Witnesses}

Another requisite to proper implementation of the behavioral evidence adduced at the trial is that the expert have sufficient prior knowledge of the witness. In some instances an examination specifically conducted for the purposes of the trial may be necessary if the psychiatrist's opinion is to meet the applicable tests of probative value. This raises the serious question of whether courts have the power to order psychiatric examinations of witnesses.

Most of the courts which have dealt with this problem have recognized the authority of the trial judge to order a psychiatric examination of a witness on the question of credibility. The principle established by the majority of the cases is that the judge has the discretion to order such an examination, although the failure to do so has rarely been held an abuse of discretion. In State v. Butler ${ }^{84}$ the defendant in a prosecution for murder moved before trial that the state's key witness, a former mental patient, be subjected to a psychiatric examination. The trial court denied the motion, but at a hearing on the witness's competency received the opinion of a psychiatrist who had examined the witness on behalf of the prosecution, ${ }^{85}$ and declared the witness competent. The decision was reversed by the Supreme Court of New Jersey, which held that the trial court had the authority to order a pretrial psychiatric examination to determine a witness's capacity to testify, ${ }^{86}$ and that the ex parte proceeding was an abuse of discretion. Although Builer is a leading case in support of the trial court's power, it gives no indication as to the standards limiting the court's discretion, except to say that there must be a "substantial showing of need and justification" before a witness should be ordered to submit to an examination.

There is only one other case in which a verdict was reversed because a prosecution witness was not submited to a psychiatric examination as to credibihty. In Burton v. Statest a conviction of sodomy was reversed because the prosecution had not taken steps to determine whether the charge was the product of hysteria. The case was subsequently overruled to the extent that it required a psychiatric examination of complaining witnesses, on the theory that courts have no authority to require the prosecu-

8427 N.J. 560, 143 A.2d 530 (1958); see Note, 13 Rutgers L. Rev. 330 (1958); see also notes 12,43 and 78 supra, and supported text.

85 See note 78 supra.

86 The opinion does not explicitly state that a trial court has the authority to order an examination as to credibility, but contains a dictum that the evidence received at the competency hearing would be admissible as affecting credibility, and that the ex parte proceeding deprived the defendant of his substantial right to contest the issue of credibility.

87232 Ind. 246, 111 N.E.2d 892 (1953). 
tion to support every conviction of a sexual offense by having the prosecutrix submit to a psychiatric examination..$^{88}$ However, the Burton case is apparently still good law in so far as it implies that the trial court may order the examination under proper circumstances.

Courts of several other jurisdictions have followed the rule that the trial court has discretion to order psychiatric examinations of witnesses to determine their credibility, although in each case the refusal to order an examination was held not to be reversible error.$^{88}$ No case clearly holds that the court lacks authority. to order such an examination of a witness. ${ }^{.00}$ Aside from the vague requirement of substantial need and justification stated in the Butler case, however, the criteria for the exercise of the court's discretion have not been defined. It must also be noted that all of the cases have involved criminal prosecutions and that the witnesses whose credibility has been in question have been prosecution witnesses, not parties. Whether civil actions present a stronger or weaker case for the exercise of such discretion may be argued either way.

The authority of a trial court to order a witness to submit to a mental examination is rooted in the doctrine of "inherent" or "implied" judicial powers. This doctrine was cited in Butler. ${ }^{91}$ It has been invoked to support the trial judge's power to summon witnesses ${ }^{82}$ and to require bail to secure the appearance of witnesses in criminal cases. ${ }^{93}$ Several courts have recognized the power of a trial judge to require complaining witnesses in prosecutions for rape to submit to physical examinations. ${ }^{94}$ However, refusal to order the examination is frequently upheld as an exercise of the trial court's

88 Wedmore v. State, 237 Ind. 212, 143 N.E.2d 649 (1957); see Note, 43 Iown L. Rev. 650 (1958); cf. Douglas v. State, 234 Ind. 621,130 N.E.2d 465 (1955); Warren v. State, 238 Ind. 401, 151 N.E.2d 149 (1958).

89 Carrado v. United States, 210 F.2d 712 (1953), cert. denied, 347 U.S. 1018 (1953); People v. Stice, 165 Cal. App. 2d 287, 331 P.2d 468 (1958); State v. Driver, 88 W. Va. 479, 107 S.E. 189 (1921); cf. People v. Hudson, 341 Ill. 187, 173 N.E. 278 (1930) ; State v. Palmer, 206 Minn. 185, 288 N.W. 160 (1939); Commonwealth v. Kosh, 305 Pa. 146, 157 Atl. 479 (1931) ; Rice v. State, 195 Wis. 181, 217 N.W. 697 (1928).

80 The closest case to such a holding is Goodwin v. State, 114 Wis. 318, 90 N.W. 170, 171 (1902).

8127 N.J. at 601, 143 A.2d at 553; see United States v. Hudson, 11 U.S. (7 Cranch) 32, 34 (1812) "Certain implied powers must necessarily result to our courts of justice, from the nature of their institution. . . . To fine for contenupt, imprison for contumacy, enforce the observance of order, \&c., are powers which cannot be dispensed with in a court, because they are necessary to the exercise of all others .....").

92 See Sink, The Unused Power of a Federal Judge to Call His Own Expert Wilness, 29 So. Cal. L. Rev. 195 (1956); Note, 12 Rutgers L. Rev. 375 (1957); Note, 34 Harv. L. REv. 321 (1821); 9 WIGMORE \& 2484.

93 Croshy v. Potts, 8 Ga. App. 463, 69 S.E. 582 (1910).

94 State v. Pucca, 20 Del. 71, 55 Atl. 831 (1902); Walker v. State, 12 Okla. Crim. 179, 153 Pac. 209 (1915); cf. Gregg v. State, 69 Okla. Crim. 103, 101 P.2d 289 (1940). 
discretion, on the ground that the prospect of examinations would deter innocent victims from bringing complaints. ${ }^{95}$

The doctrine of inherent judicial powers has also been invoked to support the authority of trial courts to order physical examinations of parties to civil litigation, ${ }^{98}$ although the basis of such orders is primarily statutory ${ }^{97}$ It may be argued analogously that courts should have the authority to order psychiatric examinations. Some indication of the judicial attitude toward psychiatric examinations is given by the responses of the courts to the various types of physical examinations which have been proposed. It has been held that a trial court may not order an examination involving a spinal puncture ${ }^{88}$ biopsy ${ }^{89}$ anaesthetic, ${ }^{100}$ or X-ray, ${ }^{101}$ nor an examination of the womb ${ }^{102}$ but recent decisions have gone far in allowing intimate and distasteful examinations. In addition to permitting use of X-rays, ${ }^{103}$ some courts have approved subjecting parties to examinations of urine and feces, ${ }^{103}$ blood, ${ }^{105}$ genitals ${ }^{108}$ and the contents of the stomach. ${ }^{107}$ One may only conjecture whether the courts will analogize these situations to a psychiatric probe into the party's past history. ${ }^{108}$

25 McGuff v. State, 88 Ala. 147, 7 So. 35 (1889) ; Thomas v. Commonwealth, $188 \mathrm{Ky} .509$, 222 S.W. 951 (1920); State v. Wilson, 361 Mo. 78, 233 S.W.2d 686 (1950); State v. Oswald, 306 S.W.2d 559 (Mo. 1957); see also Whitehead v. State, 39 Tex. Crim. 89, 45 S.W. 10 (1898); Bowers v. State, 45 Tex. Crim. 185, 75 S.W. 299 (1903).

${ }^{86}$ See Draper, Medical Examinations of Adversary Parties, 25 Rocrry Mr. L. REv. 163, $164 \mathrm{nn} .5-7$ (1953) for extensive citations; see also 8 WIGMORE $\$ 2220$.

97 See note 96 supra.

98 Riss \& Co. v. Galloway, 108 Colo. 93, 114 P.2d 550 (1941) (dictum).

${ }^{99}$ Andrus v. Fomfara, 3 N.J. Misc. 261, 127 Atl. 788 (Sup. Ct. 1925).

100 Strudgeon v. Sand Beach, 107 Mich. 496, 65 N.W. 616 (1895); Grill v. Mathieson Alkali Works, 243 App. Div. 853, 278 N.Y. Supp. 775 (4th Dep't 1935).

101 Wittenberg v. Onsgard, 78 Minn. 342, 81 N.W. 14 (1899).

102 Smith v. Spokane, 16 Wash. 403, 47 Pac. 888 (1897) (refusal, no abuse of discretion). 103 E.g., Giminez v. Great Atlantic \& Pacific Tea Co., 236 App. Div. 804, 259 N.Y. Supp. 597

(2d Dep't 1932); see Draper, supra note 96; 8 WIGMrore \$ 2220.

104 Depfer v. Walker, 125 Fla. 189, 169 So. 660 (1936); Cardinal v. University of Rochester, 188 Misc. 823, 71 N.Y.S.2d 614 (Sup. Ct. 1946), aff'd, 271 App. Div. 1048, 69 N.Y.S.2d 352 (4th Dep't 1947).

105 Beach v. Beach, 114 F.2d 479 (D.C. Cir. 1940); see note 104 supra; 1 Wigrrore $\$ 165$ a. 108 Klein v. Yellow Cab Co., 7 F.R.D. 169 (N.D. Ohio 1944); Templin v. Erkekedis, 119 Ind. App. 171, 84 N.E.2d 728 (1949).

107 Cardinal v. University of Rochester, 188 Misc. 823, 71 N.Y.S.2d 614 (Sup. Ct. 1946), aff'd, 271 App. Div. 1048, 69 N.Y.S.2d 352 (4th Dep't 1947).

108 Compare Young v. Kennedy, I06 N.Y.S.2d 274 (Sup. Ct. 1951) (defendant's physician may inquire into plaintiff's medical history at pretrial examination), with Wilson v. Infentino, $76 \mathrm{~Pa}$. D. \& C. 566 (C.P. 1951) (rule staying proceedings until plaintiff submitted to pretrial "psychosomatic examination" vacated); cf. Guttmacher and Weihofen, Privileged Commurications Between Psychiatrist and Patient, 28 IND. L.J. 32, 34 (1952): "Mental ill health . . is still a matter of which patients are likely to be more ashamed than physical ill health or injury." 
Permitting the court to order psychiatric examinations to determine credibility is not a radical departure from accepted practice in similar situations, especially in civil cases where the examination is of a party. For example, statutes in many jurisdictions provide for customary examinations by court order in proceedings for commitment for insanity, mental deficiency, drug addiction and alcoholism, in proceedings under sexual psychopath statutes, and in juvenile court proceedings. In criminal cases, it is custonary in many jurisdictions to order psychiatric examinations with respect to sentencing, commitment of recidivists, and determinations of competency to stand trial and criminal responsibility. ${ }^{109}$ Although these statutory procedures provide an interesting perspective on psychiatric examinations as to credibility, it is doubtful whether any existing statutes authorizing mental examinations could be used as a basis for ordering a psychiatric examination to determine credibility. A law empowering a. family court to order psychiatric examinations of persons seeking custody of children has been held not to authorize psychiatric examinations as to credibility. ${ }^{110}$

An interesting question is presented by Rule 35 of the Federal Rules of Civil Procedure and the many state statutes modeled after it, which authorize trial courts to order a physical or mental examination of a party when his physical or mental condition is "in controversy." I11 Is mental condition "in controversy" when the examination is to test credibility?"112 It can reasonably be argued that it is when the outcome of a trial depends upon the credibility of a party, and there is substantial indication of a mental condition affecting credibility. However, the courts may be influenced by the argument that the legislatures that enacted these statutes did not conteinplate psychiatric testimony as to credibility, ${ }^{113}$ and by the doctrine that credibility is a "collateral issue,"114 hence not "in controversy."

\section{The Testimonial Privileges}

Even when the court had the implied or statutory power to order a mental examination of a witness, the duty to submit might still be limited

109 See 7 WIGMORE $\$ 2090 ; 8$ WIGMORE $§ 2220$. At least one stale has provided for a physical examination of victims of sexual assaults. Fla. Laws 1955, ch. 30228, $\S 10$, at 306 .

110 N.Y.C. DoM. REL. CT. ACr, § 61(7); In re Santos, 278 App. Div. 373, 376, 105 N.Y. S.2d 716 (1st Dep't 1951).

111 FED. R. Crv. P. 35 (1957) ; see Draper, supra note 96; 8 WTGMORE $\$ 2220$.

112 Compare Wadlow v. Humberd, 27 F. Supp. 210 (W.D. Mo. 1939) (suit for libel for attributing mental condition to plaintiff, motion for examination of plaintiff on defense of truth denied, as not immediately and directly in controversy), with Beach v. Beach, 114 F.2d 479 (D.C. Cir. 1940) (ordering blood test of mother and child in action for divorce on ground of adultery).

113 Some statutes bave been limited to physical examinations of parties in personal injury actions. Herskovitz v. Travelers Ins. Co., 272 App. Div. 584, 73 N.X.S.2d 851 (1st Dep't 1947); see Draper, supra note 96.

114 See note 67 supra, for decisions disapproving of psychiatric testimony on the "col- 
by one of the testimonial privileges. The privilege against self-incrimination, for exainple, may be a significant restraint on compelling witnesses to submit to psychiatric examinations. In criminal cases, the privilege would protect ordinary witnesses as well as the accused, ${ }^{115}$ and in civil cases it would apply to any witnesses from whom the facts to be elicited related to the commission of a crime. ${ }^{116}$ The privilege has been applied to the taking of depositions and pre-trial interrogatories, ${ }^{117}$ and thus may be sufficiently broad to cover any procedural stage at which a witness might be required to submit to an examination.

The privilege also extends to facts which may "tend to incriminate,"118 and in many cases such facts might be uncovered during a thorough psychiatric examination. A case history of a psychopath, for example, is likely to include accounts of anti-social behavior. The protection afforded by the privilege would have to be effected either by forbidding the examination, or preventing the psychiatrist from disclosing the incriminating matter. The latter alternative has the advantage of allowing the examination, thereby preserving to some extent the possibility of testing the witness's credibility, but it gives the psychiatrist too much responsibility for editing his remarks to satisfy imprecise legal principles with which he may not be familiar. There is also a danger that if the witness submitted to an examination, he would be deemed to have waived the privilege. ${ }^{119}$

The privilege against self-incrimination found in the fifth amendment does not apply to the states, ${ }^{120}$ but even in states which have not enacted their own version of the privilege, witnesses might still be protected from coercive, incriminating psychiatric examinations by the requirement of due process, ${ }^{121}$ which prohibits the use of coerced confessions. ${ }^{122}$ Although coercing a witness to submit to an unpleasant investigation of his mental condition, particularly when he is not a party to the action, might be con-

115 MCCORMICK $\S 123 ; 8$ WIGMORE $\$ 2252$.

110 E.g., Chicago v. Lord, 3 III. App. 2d 410, 122 N.E.2d 439 (1954); see note 115 subpra.

117 Neilson v. District Court, 128 Mont. 445, 277 P.2d 536 (1954); Mumford v. Croft, 93 A.2d 506 (Del. Super. 1952).

1188 WIGMORE $\$ \$ 2260-61$.

119 See Fouquette v. Bernard, 198 F.2d 860 (9th Cir. 1952) (physician who examined defendant in murder prosecution as to his sanity may testify that he was sane and give all the conversations elicited, over the objection of self-incrimination, where no allegation that coercive methods were used by the doctor or that defendant did not consent); Blocker v. State, 92 Fla. 878, 110 So. 547 (1926) (psychiatric examination of accused without his attorney's knowledge upheld where no objection by the accused).

120 Adamson v. California, 332 U.S. 46 (1947); Twining v. New Jersey, 211 U.S. 78 (1908).

121 See Watts v. Indiana, 338 U.S. 49 (1949) (use of confession obtained after six days of intensive and unreasonable questioning violates due process); Malinski v. New York, 324 U.S. 401 (1945) (introduction of involuntary confession violates due process).

122 See People v. Leyra, 302 N.Y. 353, 98 N.E.2d 553 (1951) (confession obtained by psychiatrist working with the prosecution is inadmissible, as this is a form of coercion). 
sidered a violation of due process, the cases in which the due process doctrine is customarily applied are criminal cases involving coercion of the defendant, whereas most of the cases of psychiatric ezaminations as to credibility involve prosecution witnesses or witnesses in civil proceedings. Compulsion in the latter situations might not be so distasteful as to "shock the conscience" and violate due process, ${ }^{123}$ unless the mode of examination were unusually offensive. ${ }^{124}$

Another doctrine which lias been referred to in cases involving physical examinations, and wlich might have some bearing on the duty of a witness to submit to a psychiatric examination, is that of the inviolability of the person. ${ }^{125}$ This protection has been removed, lowever, by statutes authorizing examinations of parties, by cases uploolding the inherent power of the courts to order such examinations, and by the doctrine of waiver. ${ }^{120}$ It is unlikely that courts upholding the authority of a trial judge to order a inental examination of a witness would circumscribe the examination by allusions to the inviolability of the person.

The privilege against disclosing facts involving one's humiliation, disgrace or infamy ${ }^{127}$ is another obstacle that might arise in cases involving psychiatric evaluation of testimony. The privilege, recognized to some extent at common law, las not been adopted in most jurisdictions. ${ }^{128}$ Even where the privilege has been recognized, it usually has not been applied to matter which is material and relevant as affecting credibility, ${ }^{12 \theta}$ and thus

123 Compare Rochin v. California, 342 U.S. 165 (1952) (pumping stomach of accused to recover narcotics "shocks the conscience" and violates due process), with Cardinal v. University of Rochester, 188 Misc. 823, 71 N.Y.S.2d 614 (Sup. Ct. 1946), affd, 271 App. Div. 1048, 69 N.Y.S.2d 352 (4th Dep't 1947) (court may order plaintiff in personal injury suit to submit to examination of contents of stomach).

124 Narcoanalytic interviews present the most serious threat of a violation of due process. See Silving, Testing of the Unconscious in Criminal Cases, 69 HARv. L. REv. 683 (1956); Note, 24 BrookLyN L. REv. 96 (1958); Note, 31 Tearr. L.Q. 359 (1958); cf. People v. Heirens, $4 \mathrm{~m} .2 \mathrm{~d} 13 \mathrm{I}, 122$ N.E.2d 231 (1954) (use of drug to obtain confession does not invalidate voluntary admission elicited a month later).

125 See Union Pacific R.R. v. Botsford, 141 U.S. 250 (1891); Riss \& Co. v. Galloway, 108 Colo. 93, 114 P.2d 550 (1941); cf. Goodwin v. State, 114 Wis. 318, 90 N.W. 170 (1902); Sibbach v. Wilson \& Co., 312 U.S. 1 (1941) (dissent).

126 See, e.g., Chicago \& N.W.R.R. v. Kendall, 167 Fed. 62 (8th Cir. 1909) (plaintiff in personal injury action waives privilege by showing his knees in court); 8 Wromore 82196.

127 McArthur v. State, 59 Ark. 431, 27 S.W. 628 (1894) (complaining witness in prosecution for slander privileged from an examination of her person which would tend to disgrace her); see also 10 U.S.C. $\$ 831$ (c) (1956); McCray v. State, 134 Ga. 416, 68 S.E. 62 (1910); State v. Hill, 52 W.Va. 296, 43 S.E. 160 (1903); State v. Prater, 52 W.Va. 132, 43 S.E. 230 (1903); 3 WIGMORE $\$ \$ 984,986-87,8$ WIGMORE $\$ 82215,2255$.

128 In re Vince, 2 N.J. 443, 67 A.2d 141 (1949) (reviewing the "checkered history" of the privilege); 8 WrOMORE $\$ \& 2215$, 2255; cf. Brown v. Walker, 161 U.S. 591 (1896) (privilege against self-incrimination does not apply to disgrace attaching to exposure of crime; immunity statute upheld).

12910 U.S.C. 8831 (c) (1956); State v. Hill, suspra note 127; State v. Prater, 52 W.Va. 132, 43 S.E. 230 (1903). 
may not apply to psychiatric opinions as to the credibility of important witnesses.

The privilege against disclosure of confidential communications between doctor and patient, on the other hand, has a significant bearing on the admissibility of the results of psychiatric interviews. The "doctor-patient" privilege obtains in thirty-one states, ${ }^{130}$ and has been held to apply to communications between a psychiatrist and his patient. ${ }^{131}$ A statutory "psychiatrist-patient" privilege has been enacted in at least seven jurisdictions. ${ }^{132}$ The privilege may reasonably be applied to testimony of a psychiatrist on the issue of the credibility of one of his patients, but probably would not be applied to material elicited during an examination conducted solely for the purpose of trial. ${ }^{133}$

The doctor-patient privilege has been disapproved on the grounds that it removes a reliable source of facts necessary to the decision of cases, enables a patient to testify falsely without contradiction, and has no compensating tendency to facilitate frank disclosure of information to the doctor. ${ }^{134}$ Psychiatrists have argued that even if these criticisms are valid as to the privilege against disclosures by an ordinary physician, a "psychiatrist-patient" privilege is less liable to abuse and is supported by the "therapeutic importance of confidentiality."135 One might add that the privilege has political implications, reducing the area in which the state may compel disclosure of private behavior. Since the resolution of the conflict depends upon the circumstances of the particular case, a solution might be to recognize the psychiatrist-patient privilege, with the proviso that the trial judge may compel disclosure where there is a substantial need and justification, taking into consideration the role of the witness in the litigation.

130 Note, 54 Mrch. L. Rev. 423 (1956); see MCCormick \$§ 101-08; 8 WrgMore $\$ \$ 2380-91$. 131 Taylor v. United States, 222 F.2d 398 (D.C. Cir. 1955); see also Guttmacher and Weihofen, Privileged Communication Between Phychiatrist and Patient, supra note 108, reporting an Illinois trial in which the court applied the privilege to communications to a psychiatrist; Linscott v. Hughbanks, 140 Kan. 353, 37 P.2d 26 (1934) (physician-patient privilege covers communications between inmate of mental institution and staff doctors).

132 D.C. Code ANn. \$ 14-308 (Supp. 1959); Ga. Code ANn. \$ 84-3118 (1955); Kx. Rev. Stat. ANN. $\$ 319.110$ (1960) ; N.Y. Educ. Law $\$ 7611$; Tenn. Code ANN. $\$ 63-1117$ (1956); Ark. Acts 1955, No. 129, $\& 16$, at 313; Wash. Laws 1955, ch. 305, §11, at 1371; see Louisell, The Psychologist in Today's Legal World: Part II, 41 MnNo. L. Rev. 731 (1957).

133 See Fouquette v. Bernard, 198 F.2\& 860 (9th Cir. 1952) (doctor-patient privilege does not apply between crimimal defendant and physician examining him as to his sanity); Simeck v. State, 243 Wis. 439, 10 N.W.2d 161 (1943) (same); see also Annot., 107 A.L.R. 1495 (1937). 134 Chafee, Privileged Communications: Is Justice Served or Obstructed by Closing the Doctor's Mouth on the Witness Stand?, 52 YALE L.J. 607 (1943); McCorMICK $\$ 108$.

135 Guttmacher and Weihofen, Privileged Communications Between Phychiatrist and Patient, supra note 108; see also Note, Psychiatric Challenge of Witnesses, 9 VAND. L. REv. 860 (1956). 


\section{Enforcement of the Court Order}

Once the issue of whether the examination may be ordered is resolved, there still remains the problem of enforcement of the order. It is apparent that a court cannot force a witness to have the examination. The value of a psychiatric examination of an uncooperative subject may be very limited, and the subject has the power to frustrate the examination. ${ }^{136}$ There may be sanctions by which the court could persuade the witness to cooperate. The most practical is to cite him for contempt, although it is unlikely that the courts would be-willing to order confinement of the witness except in special cases. ${ }^{137}$ The procedure of allowing the opposing party to comment on a refusal to be subjected to an examination ${ }^{138}$ would be of little value because of the uncertainty concerring the inferences that can be drawn from a witness's refusal to submit to a psychiatric examination. The court might also stay the proceeding or dismiss the case where the witness is the civil plaintiff or criminal complainant, or bar him from testifying. ${ }^{130}$

Exposing the problems of implementing psychiatric evaluations of credibility in the context of a trial is merely a small part of the task of formulating a framework for the reception of this kind of evidence. The bulk of this article has been an attempt to indicate how the legal profession might orient itself with respect to the psychiatric material, so that the information may be effective as a test of credibility.

The discussion thus far has been primarily theoretical, rather than descriptive of the legal scene, and would not be complete without reference to soine of the common situations in which psychiatric opinions as to

130 Gutmacher \& Wemrofen, Psychitry and the Law 286-87 (1952); cf. Myers v. Travelers Ins. Co., $353 \mathrm{~Pa}$. 523, 46 A.2d 224 (1946) (court cannot actually compel a physical examination).

137 See Sibbach v. Wilson \& Co., 312 U.S. 1 (1941); People v. Redlich, 402 Ill. 270, 83 N.E.2d 736 (1949) (contempt and confinement for failure to comply with order to submit to a psychiatric examination under a sexual psychopath statute; validity of the sanction not decided).

138 See Denver C.T. Co. v. Norton, 141 Fed. 599, 609 (1905) (personal injury; inspection of plaintiff cannot be ordered, but defendant may comment on refusal to submit) ; Freeport v. Isbell, 93 III. 381, 385 (1879) (plaimtiff may be asked whether he would submit to urinanalysis; refusal is evidence against him); Russell v. Celentano, $13 \mathrm{La}$. App. 708, 129 So. 182 (1930) (refusal open to inference). Compare State v. Kolander, 236 Minn. 209, 52 N.W.2d 458 (1952) (prejudicial error to admit evidence of defendant's refusal to submit to narcoanalysis), with People v. Draper, 304 N.Y. 799, 109 N.E.2d 342 (1952) (prosecution may comment on defendant's refusal to undergo narcoanalysis).

139 Note, 59 YaLE L.J. 1324, 1339-40 (1950); see Burton v. State, 232 Ind. 246, 111 N.E.2d 892 (1953), note 87 supra; cf. Scheffier v. Lee, 126 Md. 373, 94 Atl. 907 (1915) (plaintiff in personal injury action refused to submit to examination ordered by trial court; judgment entered against her) ; Hess v. Lake Shore \& Michigan Southern R.R., 7 Pa. County Ct. 565 (1890) (court refused to try case until coinpliance with order); Myers v. Travelers Ins. Co., $353 \mathrm{~Pa} .523,46 \mathrm{~A} .2 \mathrm{~d} 224$ (1946) (plaimtiff can be refused permission to proceed with suit until examination permitted). But see Wedmore v. State, 237 Ind. 212, 143 N.E.2d 649 (1957), note 88 supra; see also Bagwell v. Atlantic Consol. St. Ry., 109 Ga. 611, 34 S.E. 1018 (1900); 
credibility have been offered. The ensuing remarks should illustrate further the problems discussed above and indicate the prospects for future use of psychiatric evidence.

\section{IV}

TESTIMONY BY THE PSYCHOPATHIC PERSONAIITY

The psychiatric testimony in United States $v$. Hiss ${ }^{140^{\circ}}$ defined psychopathic personality as a "character disorder" characterized by amoral, asocial and delinquent behavior, such as theft, pathological lying and deceiving; bizarre or eccentric behavior; abnormal emotionality; instability of attachments; paranoid ideas; and the disposition to assume a role and to assign roles to others and believe them fully. ${ }^{141}$ "Psychopathic personality" is obviously a very broad term; it is intended to designate a class of people who cannot be considered normal from the point of view of society nor abnormal in the sense of being insane, but who deviate conspicuously from conventional modes of social adaptation. ${ }^{142} \mathrm{~A}$ true psychopath, it has been said, has a "distorted or deficiency of conscience."143 This condition can have a severe effect on credibility. The capacities to observe and to recollect are apparently unimpaired, but the sense of moral responsibility to narrate truthfully is affected. The condition might render the witness "so careless with the truth as to always be suspect," "impulsive," and "undependable." of the existence of the psychopathy or understand its relationship to the capacity to testify, ${ }^{145}$ expert testimony would be justified, ${ }^{146}$ assuming the other conditions were met.

140 See note 33 supra; see also Brief for Appellant, pp. 73-74, United States v. Hiss, 185 F.2d 822 (2d Cir. 1950).

141 With respect to the assumption and assignment of roles, the psychiatrist found "extraordinary analogies" of "medical significance" between a story Chambers had translated, Franz Werfels' Class Reunion, and facts about Chambers' relationship to Hiss recounted in the defense attorney's hypothetical question.

142 Roche, Truth-Telling, Psychiatric Expert Testimony and the Impeachment of Witnesses, 22 PA. B.A.Q. 140 (1951); see also Carieron \& MAGaret, op. cit. suspra note 80, ch. 7 ; Davioson, Forenstc Psychiatry 217-20 (1952); Guttuacher \& Wemofen, Psychiatry and THE LAw ch. 5 (1952); Lipton, The Psychopath, 40 J. CRTMr. L., C. \& P.S. 584 (1950); Curran and Mallinson, Psychopathic Personality, 90 J. MEN. Scr. 266 (1944).

143 H. B. Witten, V.A. Hospital, Oklahoma City, in Mack, sucpric note 2, n.58 at p. 314; see LINDNER, REBel WrTEout a CAUSE (1944), attributing psychopathy to a stunting of the super-ego.

144 H. S. Whiting, Connecticut State Hospital, and H. B. Witten, V.A. Hospital, Oklahoma City, in Mack, supra note 2, n.57 and 58 at p. 314 .

145 Davidson, Testimonial Capacity, 39 B.U.L. REv. 172, 179 (1959) ; "The juror cannot understand why an apparently intelligent person would perjure himself when he had so little to gain by it. The psychiatrist would know that the psychopath bears false witness because he enjoys being in the limehght (even if he degrades himself); or to vent an unconscious hostility .... The malevolence which drives a psychopath into a testimomial network of lies is utterly beyond the ken of the psychiatrically unlearned jurist or juror." Cf. CLECKLEx, MASK of SANity (1941).

${ }^{146}$ See text at note 67 suspra. 
In addition to United States $v$. Hiss, there have been other cases in which the courts have had to determine the admissibility of a psychiatric opinion that a witness is a psychopathic personality, and the decisions have not been uniform. ${ }^{147}$ Such testimony has been received without issue in several cases, ${ }^{148}$ and extrinsic evidence of psychopathic personality, unaccompanied by expert testimony, has been held admissible as affecting credibility. ${ }^{14 \theta}$

Before legal rules as to the admissibility of evidence of psychopathy are further evolved, there is serious need for study of the relevancy of such evidence and of the problems of implementing such a test of credibility at the trial. Under the standard of relevancy and probative value which prevails in cases where the admissibility of psychiatric testimony as to credibility is in issue, naniely, general scientific acceptance of the theory upon which the opinion is based, an opmion that a witness is a psychopathic personality would have to be excluded. There is nothing close to a consensus of psychiatrists that the classification "psychopathic personality" is valid; in other words, psychiatrists are not even agreed that there is such a disease, nuch less that it affects credibility or can be reliably diagnosed. Critical psychiatrists claim that the classification has been used to designate every type of abnormal character, ${ }^{150}$ is a "convenient screen against which to project theoretical preconceptions" and "practically useless for definitive purposes," as to what a psychopath is, [or] . . . to the tenuous validity of the concept."152 Even if the concept were sufficiently accepted by psychiatrists to be coinpetent as the basis of an opinion as to the credibility of a witness,

147 See note 33 stapra; State v. Browning, 98 Ohio App. 8, 128 N.E.2d 173 (1954). Cortra, Commonwealth v. Repyneck, 181 Pa. Super. 630, 124 A.2d 693 (1956) (burglary and larceny; no error to exclude from jury testimony of two psychiatrists and a clinical psycbologist that prosecution witness was a psychopathic personality, received at a hearing on competency); see also State v. Driver, 88 W.Va. 479, 107 S.E. 189 (1921) (attempted rape; no error to exclude testimony that prosecutrix was a "lying moron," "moral defective," and "defective delinquent"; apparently the phrase "psychopathic personality" was not yet in vogue); cf. Commonwealth v. Bartell, $184 \mathrm{~Pa}$. Super. 528, 136 A.2d 166 (1957) (no error to deny defendant's petition before trial to appoint psychiatrists to determine competency of principal prosecution witness, alleged psychopathic personality).

148 People v. Bastian, 330 Mich. 457, 47 N.W.2d 692 (1951); People v. Cowles, 246 Mich. 429, 224 N.W. 387 (1929); State v. Wesler, 1 N.J. 58, 61 A.2d 746 (1943), affirming 137 N.J.L. 311, 59 A.2d 834 (1948).

140 Coffin v. Reichard, 148 F.2d 278 (6th Cir. 1945), cert. denied, 325 U.S. 887 (1945); People v. Bastian, supro note 148; Commonwealth v. Towber, $190 \mathrm{~Pa}$. Super. 93 , 152 A.2d 917 (1959).

150 Curran and Mallinson, sispra note 142.

151 Cameron \& Magaret, Bemaviour Pathology 190 (1951).

152 Roche, Truth-Telling, Psychiatric Expert Testimony and the Impeachment of Witnesses, 22 PA. B.A.Q. 140, 148 (1951). 
there would still remain the problem whether the theory of the effect of the condition upon credibility was reliable; psychiatrists might accept the notion that a witness may be a psychopathic personality, but disagree as to its relevancy to lis behavior as a witness. ${ }^{153}$ This is another area where lawyers slould frame questions to guide future psychiatric research. Other necessary information concerns the diagnostic methodology which would be required to qualify the psychiatrist's opinion under the prevailing judicial test of probative value.

A psycliatrist's opinion that a witness is a psychopathic personality also creates perplexing problems with respect to the exclusion of evidence which would prejudice a just verdict and the reduction of harm to witnesses. ${ }^{154}$ Some of these problems can be avoided by deleting inflammatory language and by focusing the testimony on the specific matters in issue, that is, the "conscience" of the witness to tell the truth about the particular subject of his testimony while he is on the stand. Consideration might also be given to the possibility that the concept of the "psychopathic personality," while not approved by many psychiatrists for definitive purposes, embodies theories which may have validity for other psychiatric or forensic purposes. The impressive list of terms which have been used to express the concept, such as "moral insanity," "constitutional psychopathic inferiority," "moral agenisis," "inadequate social deviant," "mept social deviant" and "delinquent," 155 indicates that psychiatrists have not agreed about what a psychopath is; but it also shows the tenacity of the concept and suggests that there may be useful underlying theories about which psychiatrists might agree, although rejecting the overall concept as a "wastebasket category, and not a psychopathogical entity. ${ }^{168}$

\section{PROSECUTIONS FOR SEXUAL OFFENSES}

Prosecutions for sexual offenses should be considered separately by students of psychiatric evaluation of credibihty for two reasons. First, in these

183 "The diagnosis of 'psychopathic personality' implies the discovery of a static, immutable state or condition of the person so diagnosed. This is a contradiction of our everyday observation that we are never the same from day to day. ... Medieval man adjudicated a heretic could hope for absolution, but modern man stigmatized as a psychopathic personality can only despair." Roche, supra note 152 , at 151.

164 "The diagnosis of psychopathic personality in the hands of one's private psychiatrist is privileged, but used as a weapon of impeachment in the court or as a label for the delinquent, it becomes public property abandoned to the community to any mischief it wishes to make of it." Roche, supra note 152 , at 152-53.

155 CAMIERoN \& MAGARET, supra note 151, at 187-211; see Roche, supra note 152, at 148.

158 Witten, supra note 143 . Significantly, the psychiatrist who used this characterization was still willing to express an opinion as to the testimony of psychopaths. 
cases the policy of enabling the triers to evaluate credibility is given a prominence which it does not have in other cases. It is a familiar point to courts and legal scholars that sex cases create a special need for an evaluation of credibility. The accusation is "easily to be made and harder to be defended," the penalties are high, and often the charge incites sympathy for the prosecutrix and prejudice against the defendant. ${ }^{157}$ Secondly, this type of litigation is especially likely to involve pathological witnesses, the prosecuting witness in particular.

Prosecutions for sexual offenses are a rich field for psychiatric research on mental conditions affecting credibility. One such condition which has been of interest to the legal profession is the disposition of some women to fabricate stories of sexual attacks. "Most women," according to a prominent psychiatrist, "entertain more or less consciously at one time or another fleeting fantasies or fears that they are being or will be attacked by a man. Of course, the normal woman who has such a fantasy does not confuse it with reality, but it is . . . easy for some neurotic individuals to translate their fantasies into actual beliefs and memory falsifications . . ." 168 The accusation may be the product of a wishful biological urge or aggressive tendency directed to the person accused, a childish desire for notoriety, and in the case of mental defectives a failure to appreciate the significance and consequences of the accusation. ${ }^{158}$

Aggravating these problems is the fact that most states adhere to the common law rule that in a trial for rape the testimony of the prosecutrix alone is sufficient for a conviction. ${ }^{160}$ Some states require corroboration by other evidence, ${ }^{161}$ but courts have accepted weak evidence in substantia-

157 See State v. Wulff, 194 Minn. 271, 274, 260 N.W. 515, 516 (1935) for a classic statement of the problem, replete with a quotation from Lord Hale; see also PLoscowe, SEX AND THE LAW 187-90, 194 (1951); Note, 28 NEB. L. REV. 132 (1948); 3 Wigurore $8 \S 924 a, 934 a$.

$158 \mathrm{Karl}$ Menninger, in 3 WIGMORe $\S 924 \mathrm{a}$, at $463-64$.

159 William A. White, in 3 WIGMORE $\S 924 a$, at $464-65$; in addition to Wigmore's influential study, see Deutsch, Psychology of Women I 123-27, 256-67, and Psychology of Women II 194-201, 374 (1945), collected in Materials for Psychiatry and Law Seminar, Yale Law School 1959, pp. 226-36; Overholser, THe Psychatrist and the Law 51-54 (1953); 3 Wigmore § 934a; Ploscowe, supra note 157; Colnment, Phychiatric Testimony for the Impeachment of Witnesses in Sex Cases, 39 J. CrDM. L., C. \& P.S. 750 (1949) ; Coinment, PreTrial Psychiatric Examination as Proposed Means for Testint the Complainant's Competency to Allege a Sex Offense, 1957 U. Irx. L.F. 651 ; Note, Psychiatric Aid in Evaluating the Credibility of a Prosecuting Witness Charging Rape, 26 IND. L.J. 98 (1950); cf. People v. Smallwood, 306 Mich. 49, 10 N.W.2d 303 (1943).

1607 WIGMORE $\S 2061$.

161 State v. Hines, 43 Idaho 713, 254 Pac. 217 (1927); State v. Bowker, 40 Idaho 74, 231 Pac. 706 (1924) ; People v. De Frates, 395 I1l. 439, 70 N.E.2d 591 (1946) ; Fox v. Commonwealth, $299 \mathrm{Ky} .293$, 185 S.W.2d 394 (1945) ; Cascio v. State, 147 Neb. 1075, 25 N.W.2d 897 (1947) ; Roberts v. State, 106 Neb. 362, 183 N.W. 555 (1921) ; People v. Romano, 279 N.Y. 392, 18 N.E.2d 634 (1939); Miller v. State, 49 Okla. Crim. 133, 295 Pac. 403 (1930); State v. Scott, 20 Wasb. 2d 696, 149 P.2d 152 (1944); IowA CoDs $\$ 782.4$ (1958); N.Y. PEN. LAW § 2013. 
tion, ${ }^{162}$ and in some courts corroboration is not required if the prosecutrix' testimony is "clear and convincing." 103

The responsibility for evaluating the complaining witness's credibility under these circumstances is a heavy one. To help the jury, some courts have admitted extrinsic evidence of the prosecutrix' mental condition, under the traditional principle of impeachment that evidence of incapacity is admissible as bearing on credibility; ${ }^{104}$ and in this type of case more than most others, courts have held admissible psychiatric opinions as to credibility, ${ }^{165}$ although the judicial attitude towards ordering psychiatric examinations of prosecuting witnesses has been unfavorable. ${ }^{168}$

The disposition of the courts to allow psychiatric evaluation of the credibility of complaining witnesses in prosecutions for sexual offenses is probably attributable to the special problems raised in such cases rather than a prevailing judicial approval of psychiatric evidence. Standards of relevancy and the concern for disposing of the trial with minimum expense

162 Fox v. Commonwealth, supra note 161 (evidence that prosecutrix and defendant's alleged accomplice had venereal disease; defendant did not); People v. De Frates, supro note 161 (complaint soon after alleged crime); Miller v. State, suppra note 161 (prompt complaint); State v. Scott, supra note 161 (fact that defendant registered in a hotel with prosecutrix); cf. Shannon v. State, 233 Ind. 666, 122 N.E.2d 81 (1954) (conviction valid where defendant prevented corroboration by proper objection).

183 People v. Hiddleson, 389 Ml. 293, 59 N.E.2d 639 (1945); People v. Vaughn, 390 Ill. 360, 61 N.E.2d 546 (1945); see State v. Merryman, 79 Ariz. 73, 75, 283 P.2d 239, 241 (1955) (no corroboration required unless charge "physically impossible or so incredible that no reasonable man could believe it," quoting from State v. Pollock, 5 † Ariz. 415, 417, 114 P.2d 249, 250 (1941)).

164 State v. Alberts, 199 Iowa 815, 202 N.W. 519 (1925); People v. Bastian, 330 Mich. 457, 47 N.W.2d 692 (1951); People v. Cowles, 246 Mich. 429, 224 N.W. 387 (1929); see also Jeffers v. State, 145 Ga. 74, 88 S.E. 571 (1916). But cf. Mell v. State, 133 Ark. 197, 202 S.W. 33 (1918); People v. Dye, 81 Cal. App. 2d 952, 185 P.2d 624 (1947); People-v. Harrison, 18 Cal. App. 288, 123 Pac. 200 (1912); State v. Teager, 222 Iowa 391, 269 N.W. 348 (1936).

165 People v. Cowles, supra note 164 (testimony of doctors based on courtroom observation that prosecutrix was pathological falsifier, nymphomaniac and sexual pervert; dictum); Miller v. State, 49 Okla. Crim. 133, 295 Pac. 403 (1930) (testimony of doctors based on hypothetical question that prosecutrix was nymphomaniac and because of diseased mind would imagine that defendant had intercourse with her); State v. Pryor, 74 Wasl. 121, 132 Pac. 874 (1913) (abortion; testimony that complainant was suffering from hysteria causing delusions and hallucinations); State v. Perry, 41 W.Va. 641, 24 S.E. 634 (1896) (prosecution of doctor for raping patient; testimony based on hypothetical question that charge could be result of hallucination induced by chloroform); see Derwin v. Parsons, 52 Mich. 425 , 18 N.W. 200 (1884) (action for assault and battery; proper to show that plaintiff was afficted with a particular disease and then to show by expert testimony that such women were liable to hallucinations about the conduct of men toward them); see also People v. Bastian, suppra note 164; State v. Wesler, 1 N.J. 58, 61 A.2d 746 (Sup. Ct. 1948), affirming 137 N.J.L. 311, 59 A.2d 834 (1948); Rice v. State, 195 Wis. 181, 217 N.W. 697 (1928). Contra, State v. Driver, 88 W.Va. 479, 107 S.E. 189 (1921); cf. Lindsey v. United States, 237 F.2d 893 (9th Cir. 1956).

108 See People v. Stice, 165 Cal. App. 2d 287, 331 P.2d 468 (1958); Wedmore v. State, 237 Ind. 212, 143 N.E.2d 649 (1957), overruling Burton v. State, 232 Ind. 246, 111 N.E.2d 892 (1953) ; cf. Goodwin v. State, 114 Wis. 318,90 N.W. 170 (1902). 
and delay can be relaxed when other values are so important. On the other hand, there is still considerable work which can be done to improve this source of proof. The legal profession must learn more about the mental conditions which can have a bearing on testimony in this type of litigation, their precise effect on credibility, and the methods of evaluation necessary to meet the test of general scientific acceptance.

Use of psychiatric testimony in sex cases also creates problems regarding the exammation of witnesses. Commentators have suggested that mental examinations of the complainant and expert testimony should be required in every sex case, ${ }^{167}$ or in such cases where corroborative evidence was lacking. ${ }^{168}$ The latter scheme might be workable if coupled with a requirement that the defendant confirm the need for the examination. This requirement should not be rigorous, because that would assume that the defendant already had evidence of derangement, whereas the basis of the proceeding would be the difficulty of detecting the incapacity and the probability of its existence. A social history of the complainant, available to the defendant and prosecutor, would be useful as a preliminary and could even be the product of a routine police investigation. Until some of the other problems already discussed are solved, however, a full-fledged psychiatric evaluation of the credibility of complaining witnesses in every prosecution for a sexual offense should be postponed. ${ }^{160}$

\section{VI}

\section{TESTIMONY BY DRUG ADDICTS}

The effect of drug addiction on credibility has been in issue in more reported cases than any other defect, but both the legal and psychiatric professions are undecided upon the solution to this problem. It is well estabhished that drug addiction does not disqualify a witness. ${ }^{170}$ Most courts liave admitted evidence of addiction or the use of narcotics, ${ }^{172}$ subject in some

1673 WIGxore $\$ 924 a$; see also Burton v. State, supra note 166 ; the adherents of this view have not indicated how to solve the problem that undue harm might result to the defendant if the prosecutrix "passed" the examination.

188 Comment, 1957 U. IrL. L.F. 651 ; Note, 26 InD. L.J. 98 (1950).

160 See the Appendix, infra, for an illustration of how the framework proposed above might be applied in a prosecution for rape.

170 See note 18 supra. Confessions of drug addicts or persons under the influence of drugs have not been excluded. See Note, 24 Brooriyn L. REv. 96, n.2 (1957).

171 Wilson v. United States, 232 U.S. 563 (1914); People v. Crump, 5 Ill. 2d 251, 125 N.E.2d 615 (1955); State v. Prentice, 192 Iowa 207, 183 N.W. 411 (1921); People v. Webster, 68 Hun 11, 22 N.Y. Supp. 634 (Sup. Ct. 1893), afj'd, 139 N.Y. 73, 34 N.E. 730 (1893) ; Conmonwealth v. Morrison, 157 Pa. Super. 366, 43 A.2d 400 (1945); Beland v. State, 86 Tex. Crim. 285, 217 S.W. 147 (1920); Lankford v. Tombari, 35 Wash. 2d 412, 213 P.2d 627 (1950). Contra, Webb v. People, 97 Colo. 262, 49 P.2d 381 (1935) ; Franklin v. Franklin, 90 Tenn. 44, 16 S.W. 557 (1891); see State v. Jordan, 146 Ore. 504, 26 P.2d 558 (1933); cf. Weaver v. United States, 111 F.2d 603 (8th Cir. 1940). Annot., 52 A.L.R.2d 848 (1957). See also 3 WiGsrore 8934 ; Rossman, Testimony of the Drug Addicts, 3 Ore. I. REv. 81 (1924); Comment, 
jurisdictions to the condition that the evidence show that the witness was under the influence of drugs at the time of the trial or the events in his testimony, or that the drugs affected his mind or memory. ${ }^{172}$ However, the courts are in conflict over the most important issue, namely, the admissibility of an expert opinion as to the effect of addiction on credibility. ${ }^{173}$

This conflict in the cases reflects the disagreement among physicians and psychiatrists as to the influence of drugs. There is considerable disagreement among psychiatrists, for example, as to the effect of addiction on truthfulness. One of the leading judicial studies finds an opinion of a "considerable body of medical writers" that drugs render their users morally depraved and make them "inveterate liars," "unreliable" and "untrustworthy and regardless of truth." ${ }^{174}$ Subsequent surveys of the psychiatric profession have also disclosed the opinion that narcotic addicts are disposed to twist facts and to tell outright falsehoods. ${ }^{175}$ But according to the more modern theory, drugs do not convert addicts into hars. Under this theory, addiction is a symptom of an underlying illness which could impair the capacity to testify, but otherwise the addicts are not usually abnormal or untruthful with respect to matters not connected with the habit. "If he could maintain a steady and unvarying supply of his drug," writes one psychiatrist, "the addict would, for all practical purposes, be normal."178

172 Standard Oil Co. v. Carter, 210 Ala. 572, 98 So. 575 (1924); Nelson v. State, 99 Fla. 1032, 128 So. 1 (1930); Eldridge v. State, 27 Fla. 162, 9 So. 448 (1891); Gordon v. Gilmore, $141 \mathrm{Ga} .347,80$ S.E. 1007 (1914) ; McDowell v. Preston, 26 Ga. 528 (1858); Botkin v. Cassady, 106 Iowa 334, 76 N.W. 722 (1898); State v. Gleim, 17 Mont. 17, 41 Pac. 998 (1895); State v. Juliano, 103 N.J.L. 663, 138 Atl. 575 (1927).

173 Admissible, Chicago \& N.W. Ry. v. McKenna, 74 F.2d 155 (8th Cir. 1934) (dictum); State v. Fong Loon, 29 Idaho 248, 158 Pac. 233 (1916) (dictum); Effinger v. Effinger, $48 \mathrm{Nev}$. 205, 239 Pac. 801 (1925); Markowitz v. Markowitz, 290 S.W. 119 (Mo. App. 1927) (semble); Anderson v. State, 65 Tex. Crim. 365, 144 S.W. 281 (1912); State v. Smith, 103 Wash. 267, 174 Pac. 9 (1918); see State v. Robinson, 12 Wash. 491, 41 Pac. 884 (1895); People v. Bell, 138 Cal. App. 2d 7, 291 P.2d 150 (1955); see also Vamvas v. United States, 13 F.2d 347 (5th Cir. 1926). Contra, Kelly v. Maryland Casualty Co., 45 F.2d 782 (W.D. Va. 1929), aff'd, 45 F.2d 788 (4th Cir. 1930); State v. King, 88 Minn. 175, 92 N.W. 965 (1903); Katleman v. State, 104 Neb. 62, 175 N.W. 671 (1919); People v. Williams, 6 N.Y.2d 18, 159 N.E.2d 549 (1959); Cannon v. Territory, 1 Okla. Crim. 600, 99 Pac. 622 (1909) (dictum); Williams v. United States, 6 Indian Terr. 1, 88 S.W. 334 (1904); see also State v. Schuman, 89 Wash. 9, 153 Pac. 1084 (1915).

174 Kelly v. Maryland Casualty Co., supra note 173, at 784; as examples of judicial decisions based upon this view see Effinger v. Effinger, supra note 173; State v. Fong Loon, supra note 173; Markowitz v. Markowitz, supra note 173; Anderson v. State, supra note 173. Cf. note 64 supra and supported text.

175 Mack, Forensic Psychiatry and the Witness-A Survey, 7 Crev.-MaR. L. REv. 311 at note 42 (1958).

176 Davidson, Testimonial Capacity, 39 B.U.L. REv. 178 (1959); see also Kelly v. Maryland Casualty Co., 45 F.2d 782 (W.D. Va. 1929), aff'd, 45 F.2d 788 (4th Cir. 1930); People v. Williams, 6 N.Y.2d 18, 159 N.E.2d 549 (1959); People v. Bell, 138 Cal. App. 2d 7, 291 P.2d 150 (1955); Mack, supra note 175, n.41 at p.311. 
This view is subject to the caution that if the addict is deprived of the narcotic, he may perjure himself to obtain the drug; but it also entails the paradox that the addict may be most credible when using the drug. ${ }^{177}$ Whatever the future resolution of the dispute, at present the difference of opinion among medical men would disqualify as evidence psychiatric opinions that narcotic addicts are hars.

Other effects of narcotic addiction about which psychiatrists and physicians are in dispute are the influence of drugs on the capacity to observo and on the capacity to narrate intelligently what is observed. ${ }^{178}$ There is also disagreement over the extent to which addiction impairs recollection, although the predominant medical view is that long addiction and large consumption of drugs are usually detrimental to memory. ${ }^{170}$ Therefore, before the juridical system can adopt a definitive position respecting expert opinions of the credibility of narcotic addicts, there is a need for considerable psychiatric research into the effects of drugs on memory, perception and the sense of moral responsibility to tell the truth. The legal profession also needs to know more about the distinction between the credibility of addicts and the credibility of occasional users. ${ }^{180}$

If this information were obtained, the implementation of psychiatric testimony at a trial would not be difficult. A definitive diagnosis of addiction can usually be accomplished simply and within the temporal confines of the hitigation. The primary basis of the diagnosis is withdrawal symptoms, which usually appear within twenty-four to seventy-two hours, depending upon the type of drug involved. ${ }^{181}$ If the expert opinion qualified under the applicable test of probative value, it would be desirable to receive it in evidence whenever possible, instead of receiving merely evidence of addiction without accompanying psychiatric opinions as to its relationship to

177 Cf. State v. Concannon, 25 Wash. 327, 65 Pac. 534 (1901) (user for fifteen years was administered opium on the stand; no ahuse of discretion to allow him to testify).

178 Compare Davidson, supra note 176 (immediate effect is passivity and impairment of alertness and acuity) and Mack, supra note 175, n.36 and 37 at p. 310 (under influence of drugs, testimony and perception would be "no good") with MCDowell, D.J., in Kelly v. Maryland Casualty Co., 45 F.2d 782 (W.D.Va. 1929), aff'd, 45 F.2d 788 (4th Cir. 1930) (froin the usual dose addicts merely obtain freedom from withdrawal pains) and Report to the Council on Pharmacy and Chemistry of American Medical Association: What to do With a Drug Addict, 149 A.M.A.J. 12201221 (1952) ("... there are no pathognomonic physical signs of addiction ... mental confusion, emotional instability, nystagmus, and ataxia are not to be expeeted .... Superficially, tolerant addicts will appear to be physically and mentally nornial unless they have been without drugs for some time . ...").

${ }^{179}$ See Kelly v. Maryland Casualty Co., 45 F.2d 782 (W.D. Va. 1929), aff'd, 45 F.2d 788 (4th Cir. 1930).

180 There are indications that non-addicts are more affected by a dose of narcotics than habitual users. See note 179 supra; see also Report to the Council on Pharmacy and Chemistry of American Medical Association, supra note 178.

181 Report to the Council on Pharmacy and Chemistry on American Medical Association, supra note 178. 
credibility; the latter procedure, which now prevails, is based upon the dubious assumption that a jury of laymen is qualified to pass on the mental capacity of drug addicts. ${ }^{182}$

\section{VII}

\section{PERSONAL IN JURY SUITS BROUGHT BY MALINGERERS}

There is another situation a brief discussion of which may clarify the proposed framework for the study of psychiatric evaluation of testimony. This is the personal injury case in which the defendant alleges that the plaintiff is malingering. ${ }^{183}$ The forensic importance of malingering is attested to by an estimate that over one-half the cases in civil litigation involve claims of psychic or physical disability. ${ }^{18:}$ There are two ways in which malingering may be disclosed to the trier of fact. The first is by direct evidence of activity inconsistent with the claim of incapacity. ${ }^{185}$ The second is by the opinion of a psychiatrist or physician that the witness is feigning the illness or injury. The latter method is comparable to the use of an expert opinion as to credibility; analagous to the testimony of a psychiatrist regarding the credibility of a drug addict, a liysterical accuser of sexual offenses or a psychopath, the expert here is giving an opinion as to the plaintiff's disposition to falsify a claim of incapacity. Many psychiatrists believe that malingering is a product of both material causes which create a pecuniary or social inducement to malinger, and personality or psychodynamic causes; "pure" malingering, uncomplicated by neurotic factors, is rare. ${ }^{186}$ Therefore, when an expert testifies that a plaintiff is shamming incapacity, implicit in his testimony is an opinion that the witness has a mental instability which affects his veracity, causing him to testify untruthfully regarding his illness or injuries. ${ }^{187}$

182 See the interesting predicament of the trial court in Kelly v. Maryland Casualty Co., 45 F.2d 782 (W.D. Va. 1929), $a f f^{\prime} d, 45$ F.2d 788 (4th Cir. 1930); the court felt hound by precedent to admit evidence of the use of drugs, but was disinclined to admit expert opinions as to the credibility of the user, thereby finding itself placing more confidence in the jury's expertise than was warranted hy the circumstances.

183 Malingering is the conscious assumption of symptoms with intent to deceive. OVERHOLSER, op. cit. supra note 159 , at 31 .

184 Smith, Cross-Examination of Neuropsychiatric Testimony in Personal Injury Cases, 4 VAND. L. REv. 1 (1950). Malingering may also be significant in criminal cases when mental incapacity is advanced as a defense. See Davmoson, Forensic Psychuatrx 159-68 (1952).

185 E.g., Klem v. Medical Bldg. Realty Co., 147 So. 122 (La. Ct. App. 1933) (walking); Johnson v. Great Northern Ry., 107 Minn. 285, 119 N.W. 1061 (1909) (working); see Smith, supra note 184.

186 Davmoson, Forensic Psychiatry 170 (1952); Siegal, Inability to Remember-Its Analysis in Mfedicolegal Orientation, 45 J. CRIMr. L., C. \& P.S., 151 (1954).

187 See Markakis v. Liberian S/S The Mparmpa Christos, 161 F. Supp. 487 (S.D.N.Y. 1958) (psychiatric opinion that libelant substantially recovered and consciously or unconsciously play-acting the role of a mental and physical cripple); Tifton Brick \& Block Co. v. Meadow, 92 Ga. App. 328, 88 S.E.2d 569, 574 (1955) (doctor may testify that plaintiff was not the "malingering type"). 
A few courts have classified such testimony as an opinion as to credibility, but have excluded the evidence on the grounds that only the jury may pass on the veracity of witnesses and that credibility is a collateral matter which cannot be the subject of extrinsic evidence. ${ }^{188}$ Most courts, on the other hand, have admitted medical opinions as to whether an alleged mental or physical incapacity is feigned or genuine. ${ }^{18 \theta}$ But the courts taking the latter position have distinguished opinions as to credibility, and have assimilated the testimony into the first inethod of disclosing malingering, namely, the adduction of direct evidence inconsistent with the witness's claim of incapacity. According to this interpretation, the psychiatrist or physician is merely giving evidence contrary to the witness's testimony without passing on his veracity; the opinion is admitted because it deals with a matter for experts and is based on theories and techniques which have gained acceptance in the profession. ${ }^{190}$

Another condition favoring admissibility of expert opinions regarding malingering is that the test of the witness's claim is relatively easy to implement in the context of a trial. Fairly dependable techniques have been devcloped for testing clairns of incapacity, based on the subject's ignorance of the proper symptoms and the improbability that he could feign them. ${ }^{191}$

188 Cole v. Lake Shore \& M.S. Ry., 95 Mich. 77, 54 N.W. 638 (1893); Henson v. Kansas City, 277 Mo. 443, 210 S.W. 13 (1919); see State v. Palmer, 206 Minn. 185, 288 N.W. 160 (1939); see also note 67 supra, for cases announcing this doctrine in other contexts.

180 Great Western Land Co. v. Barker, 164 Ark. 587, 262 S.W. 650 (1924) ; Tifton Brick \& Block Co. v. Meadow, 92 Ga. App. 328, 88 S.E.2d 569 (1955); Georgia Ry. \& Power Co. v. Howell, 28 Ga. App. 798, 113 S.E. 101 (1922); Crane Co. v. Newman, 111 Ind. App. 273, 37 N.E.2d 732 (1941); Pool v. Day, 143 Kan. 226, 53 P.2d 912 (1936); Hopson v. Union Traction Co., 101 Kan. 499, 167 Pac. 1059 (1917); Ihrie v. Anthony, 205 Md. 296, 107 A.2d 104 (1954); Campanale v. Metropolitan Life Ins. Co., 290 Mass. 149, 194 N.E. 831 (1935); Sykes v. Village of Portland, 193 Mich. 86, 159 N.W. 325 (1916) ; Bedenk v. St. Louis Public Service Co., 285 S.W.2d 609 (Mo. 1955) ; Eickunann v. St. Louis Public Service Co., 363 Mo. 651, 253 S.W.2d 122 (1952); Fries v. Berberich, 177 S.W.2d 640 (Mo. Ct. App. 1944); Perringer v. Lynn Food Co., 148 S.W.2d 601 (Mo. Ct. App. 1941); see Markakis v. Liberian S/S The Mparmpa Christos, 161 F. Supp. 487 (S.D.N.Y. 1958); Burton v. Norwich Union Indemnity Ins. Co., 146 So. 897 (La. App. 1933); Tycer v. Hartseli, 184 Ore. 310, 198 P.2d 263 (1948) ; cf. State v. Haun, 224 N.C. 128, 29 S.E.2d 449 (1944); Markowitz v. Milwaukee Electric Ry. \& Light Co., 230 Wis. 312, 284 N.W. 31 (1939). See also Annot., 97 A.L.R. 1284 (1935); Davidson, Forensic Psychiatry 159-73 (1952); Smith, supra note 184.

180 'Medical science and experience make possible a judgment as to whetluer symptoms such as were descrihed are real, imaginary or feigned, that would not be possible to a layman witnessing the medical examination, much less to a lay jury hearing from witnesses what was said and done .... Such an opimion is not one relating to the veracity of the party as a witnes, which of course would be inadmissible." Campanale v. Metropolitan Life Ins. Co., 290 Mass. 150-51, 194 N.E. 831-32 (1935).

191 Davidson, Forensic Psychlatry 343-53 (1952); Keschner, Simulation of Nervous and Mental Diseases, 44 MicE. L. REv. 715 (1946); Smith, supra note 184; cf. Bedenk v. St. Louis Public Service Co., 285 S.W.2d 609, 615 (Mo. 1955) (psycliatrist may testify on the issue of whether symptom was simulated or involuntary that "no one could imitate that type of tremor.").

One of the more difficult problems is the differential diagnosis between malingering and 
In addition, the proposed expert witness would normally have access to the plaintiff-witness, under statutes giving the trial court authority to order examinations of parties whose mental or physical condition was in controversy. It is speculative whether a court which classified the testimony as an opinion as to credibilizy would consider credibility "in controversy," but under the prevailing construction of such testimony the order would usually be a matter of course.

The cases involving expert opmions as to the genuineness of alleged mental and physical incapacities are an interesting background to the study of psychiatric evaluation of credibility. They show that the courts are reluctant to admit testimony which is frankly an opinion as to veracity, yet willing to receive the same evidence under the other doctrine because of its reliability and remoteness from everyday knowledge. Presumably, judicial approval would also obtain in the other areas in which psychiatric evaluation of testimony is offered, if the method were demonstrated to be reliable and beyond the knowledge of laymen.

\footnotetext{
"anxiety neurosis," "conversion hysteria" or "traumatic neurosis," which are genuine incapacities not accompanied by organic defects. See Markakis v. Liberian S/S The Mparmpa Christos, 161 F. Supp. 487 (S.D.N.Y.1958), wherein the respondent's psychiatric expert was of the opinion that the hbelant had traumatic psychoneurosis, conversion hysteria with a tendency to malinger; the diagnosis by the libelant's expert was a schizophrenia reaction of the paranoid type in a state of remission. The court found that the libelant was not malingering, but suffering from temporary traumatic neurosis, somatic and psychogenic back injuries, and schizoid personality.

There appears to be a consensus among psychiatrists that in the bands of a highly skilled expert, narcoanalysis can be a useful supplementary aid to detection of malingering. See Grinker \& SpIEgei, MEN Under Stress 170, 215-17 (1945); Dession, Freedman, Donnelly and Redlich, Drug-Induced Revelation and Criminal Investigation, 62 YaLE L.J. 315 (1953); Morris, Intravenous Barbiturates: An Aid in the Diagnosis and Treatment of Conversion Hysteria and Malingering, $96 \mathrm{MII}$. SUR. 509 (1945) ; see also People v. Esposito, 287 N.Y.389, 39 N.E.2d 925 (1942) (psychiatrist conducted narcoanalytic interview during court-ordered examination of defendant and testified that defendant was malingering in his claim of insanity); but cf. People v. Ford, 304 N.Y. 679, 107 N.E.2d 595 (1952).
} 


\section{APPENDIX}

\section{Prospectus for Psychiatric Examination of a Witness as to Credibihity}

\section{To: Dr. John Brown}

From: M. Juviler

Re: Jäne Smith, age 19, married, one-year-old daughter.

Events: The Public Defender's chent, Robert Jones, is awaiting trial on a charge of rape. The trial will commence Wednesday, November 25 . The complaiming witness, Jane Smith, is a married woman who "dated" Jones before and during her marriage, both before and after the alleged rape. She claims that on September 8, 1959, Jones pulled her from a car occupied by her and her sister, Mrs. Barbara Green, drove her away, beat her and committed intercourse against her will. She says that she passed out three times during the attack, but is certain that penetration occurred. Defendant Jones claims the complamant called for him voluntarily and picked him up, and that she consented to the intercourse.

Role of subject, Jane Smith: The complaining witness has given a statement to the police stating the events as described above. She is expected to give substantially the same testimony at trial. She and the defendant are the only witnesses to the alleged offense, although her story is corroborated by evidence of bruises on her face and thigh, and testimony of her sister that Jones pulled Jane from the car and drove off with her shortly before the events. In support of Jones is evidence that Jane pursued him before and after the alleged offense, and dated other men during her marriage, evidence inconsistent with her claim that she had intercourse with him because she was forced to. In rebuttal, Jane claims that she is friendly with Jones because she likes him, and that he has always treated her with respect except this one time, when he was out of character. Jane has tried unsuccessfully to convince the State to drop the case, but the State will prosecute because she continues to confirm her original statement to the police.

In most rape prosecutions, as here, the State's case rests on the testimony of one witness, the alleged victim. Leading students of the criminal law and prominant psychiatrists have stated that complaining witnesses in sex cases may be induced to make false accusations by mental aberrations hidden from the layman, but apparent to experts after proper examination. In view of the severity of the penalty for rape (thirty-year maximum in Connecticut), the prejudices against the defendant aroused by a charge of rape, and the credible appearance of the complainant and the sympathy towards her, it is extremely important to avoid unjust convictions by complete evaluation of her credibility, including psychiatric evaluation.

There is some evidence that the complaining witness in this case is abnormally nervous and frequently untruthful. She was treated for a nervous ailnent about a year ago in counection with the birth of her child. She takes pills for her condition, according to the defendant. She has facial twitches, bites ler nails excessively, shakes, laughs nervously and drinks frequently. There is evidence that she has often bed in connection with this case, concealing from her husband her association with the defendant, falsely denying to others that she saw Jones before and after the alleged rape, and falsely denying social acquaintance with his friends.

Purpose of the examination: Assertions of a witness on the stand, or statements to the police may be impeached by showing lack of capacity to (1) observe the events testified to; (2) recollect them; (3) narrate them truthfully to the jury. The trend of judicial decisions is that a psychiatric opinion as to the lack of this capacity is admissible to impeach the credibility of the complaining witness in a rape case. The Public Defender would like to know whether Jane Smith has any mental condition which would affect her capacity to perform any of the following testimonial functions. Secondly, if she has 
such a condition, to what extent would it tend to affect the accuracy of her testimony. Thirdly, given the scope of your examination, what is your estimate of the degree of reliability and validity of the results?

1. Ability to observe the events testified to: namely, to exercise her powers of perception so as to observe acurately what transpired between Jones and her on the night of September 8, when the rape allegedly occurred. As a lead, she claims she blacked out a few times, but that she was sure afterward that he had penetrated her. Is there anything that would color her picture of what lappened?

2. Ability to recollect the events testified to: (the events of September 8) when the statement was given to the police on September 10, and at the trial (earliest would be November 25). As a lead, in addition to the information above, the investigators have the impression that Jane is very close to her sister, and is dominated by her.

3. Ability to narrate the events truthfully: Has Jane Smith any mental condition which might affect her ability to tell the jury truthfully what happened? For exaniple, is there any medical evidence that her picture of the intercourse is influenced by fantasies? Is she a constitutionally nervous woman whose nervousness, coupled with fear of exposure as an adulteress-endangering her marriage and custody of the clild-and fear of soiling her reputation, would induce her to misrepresent what happened? As a lead, the investigators have the impression that Jane is concerned with her reputation, and thinks herself a good woman and of better noorals than nost, in spite of frequent extra-marital dating and other deception.

*This prospectus was prepared by the writer for a psychiatrist in connection with a criminal case which was tried in the Superior Court of New Haven County. (The proposed examination did not take place, for reasons not connected with this article.) The prospectus is not presented as a flawless inodel for future cases, but is intended as an example of the type of communication which should obtain between practicing lawyers and proposed psychiatric expert witnesses as to credibihty, and is offered to illustrate some of the problems and proposals discussed above. Original copy on file with Public Defender Committee, Jerome N. Frank Association, Yale Law School. (Names are fictitious.) 